\title{
Malaria Parasites: The Great Escape
}

\author{
Laurent Rénia* and Yun Shan Goh \\ Singapore Immunology Network, Agency for Science, Technology and Research (A*STAR), Singapore
}

Parasites of the genus Plasmodium have a complex life cycle. They alternate between their final mosquito host and their intermediate hosts. The parasite can be either extra- or intracellular, depending on the stage of development. By modifying their shape, motility, and metabolic requirements, the parasite adapts to the different environments in their different hosts. The parasite has evolved to escape the multiple immune mechanisms in the host that try to block parasite development at the different stages of their development. In this article, we describe the mechanisms reported thus far that allow the Plasmodium parasite to evade innate and adaptive immune responses.

Keywords: malaria, vaccine, escape mechanism, antibodies, T cells, immunosuppression, antigenic polymorphism, antigenic variation

\section{OPEN ACCESS}

Edited by:

Alexandre Morrot, Federal University of Rio de Janeiro, Brazil

Reviewed by: Miguel Prudêncio, Instituto de Medicina Molecular, Portugal Giulia Carla Marchetti, University of Milan, Italy

*Correspondence: Laurent Rénia renia_laurent@immunol.a-star.edu.sg

Specialty section: This article was submitted to Microbial Immunology, a section of the journal

Frontiers in Immunology

Received: 21 August 2016 Accepted: 17 October 2016 Published: 07 November 2016

Citation:

Rénia L and Goh YS (2016) Malaria Parasites: The Great Escape. Front. Immunol. 7:463. doi: 10.3389/fimmu.2016.00463

\section{INTRODUCTION}

Malaria, a disease caused by Plasmodium parasites and transmitted by Anopheles mosquitoes, remains one of the most deadly diseases. There are six species able to infect humans, namely, Plasmodium falciparum, Plasmodium vivax, Plasmodium ovale, Plasmodium malariae, and the zoonotic monkey malaria species Plasmodium knowlesi (1) and Plasmodium cynomolgi (2). Around 300 million cases of clinical malaria are recorded every year. Approximately, half a million deaths occur in Africa and are mainly due to P. falciparum infections (3).

Plasmodium parasites have a complex life cycle. It starts when sporozoites are inoculated into the dermis of the mammalian host by infected mosquitoes. Sporozoites are highly motile and a majority of them migrate from the skin to the capillaries for dissemination by the bloodstream $(4,5)$. They are retained in the liver where they transmigrate through Kupffer cells and hepatocytes before seeding in final hepatocytes $(6,7)$. Depending on the species of their mammalian hosts, sporozoites mature in 2-14 days. At maturity, budding vesicles called merosomes are released and are ruptured in the lung circulation where the merozoites are released, ready to infect red blood cells (RBC) (8). During the erythrocytic cycle, a fraction of parasites differentiates into male and female gametocytes which can be taken up during the feeding of an Anopheles mosquito. In the mosquito midgut, ookinetes, generated by the gametocyte fusion, cross the mosquito midgut wall and develop into oocysts. Sporozoites released from mature oocyst then migrate to the salivary gland, ready for the next round of infection during the mosquito's next blood meal.

Malaria is a disease characterized by fever, headache, chills, sweating, and vomiting (9). Unlike viral or bacterial infections, the main indication of clinical malaria is the recurrent fever which varies between species. This is due to the release of parasite toxins into the bloodstream during the erythrocytic cycles of merozoite egress and reinvasion of erythrocytes. As the infection progresses, the number of RBC decreases and this may lead to severe anemia (10). In addition, RBC containing parasites such as $P$. falciparum can also sequester in deep tissues by cytoadhering to endothelial cells (11). This may cause organ failure, and is partly responsible for cerebral malaria. All these pathologies can eventually lead to death $(9,12,13)$. 
In the last two decades, the mortality to malaria has decreased substantially (3). This results from the combined efficacy of prevention measures, such as the use of insecticide-impregnated bednets, the development and use of rapid and easy to use diagnostic tools, and the potent artemisinin-based combinations therapies against the malaria parasites (14). However, this gain of lives might be temporary. In the recent years, all these interventions have shown some limitations. With the advent of decreased efficacy of artemisinin $(15,16)$, it is now clear that new drugs and other interventions should be developed $(9,17,18)$. New drug families, such as spiroindolones $(19,20)$ and imidalopiperazines $(21,22)$ compounds, have shown promising results in phase II clinical trials in the recent years and have a great future ahead. However, a vaccine would be the most important tool in the armamentarium against malaria.

While vaccines have been readily developed for many bacterial and viral infections, there are currently no vaccines to protect against human parasites. The need to develop a vaccine to protect against malaria has been highlighted as early as the identification of the parasite in 1897 (23). There have been two schools of thought for the development an antimalarial vaccine. The first is based on the fact that naturally acquired immunity is often observed under field conditions. However, this immunity requires long period of time to develop. It first targets the disease and then the parasite (24). This immunity has been called premonition or relative immunity. It has been defined by Edmond Sergent in 1935 as "a special type of immunity connected with the persistence of living germs in the organs of the immunized host" (25). In other words, immunity is maintained as long as the host immunity is stimulated by the continuous or repeated parasite exposure. Understanding the mechanisms responsible for this premonition will help to develop a vaccine.

The other approach is based on the Jenner principle of vaccination, which was further exemplified by Louis Pasteur. Instead of letting Nature takes its course, this approach uses an inoffensive target as a formulation to induce an immune response in healthy individuals to protect against a subsequent infection. It might not be surprising, that the first attempt was reported by the same Sergent mentioned above, who was working in the Pasteur Institute in Algiers in Algeria. Sergent was able to partially protect birds from Plasmodium lophurae, an avian malaria parasite, using inactivated sporozoites (26). Decades later, in 1946, the first attempt in human was done by Heidelberger et al. using formalininactivated $P$. vivax-infected blood to immunize volunteers, however no protection was induced $(27,28)$. Jules Freund took it one step further by inventing the Freund adjuvant and combining the adjuvant with formalin-inactivated-blood infected with $P$. lophurae or $P$. knowlesi, a monkey malaria parasite. Freund was more successful in protecting ducks or rhesus monkeys, respectively $(29,30)$. However, because of its toxic side effects, the adjuvant could not be used in humans. Since then, various approaches and technologies have been used for vaccine development against the malaria parasites. Purified parasite preparation has been used as immunogens. Peptides, recombinant proteins, DNA plasmids, bacterial and viral vectors, and genetically modified malaria parasites, in combination with new adjuvants, have also been used as vaccine delivery systems (31). However, despite having more than thousands of pre-clinical trials in rodent and monkey models and more than 200 trials in humans, very few vaccine candidates have shown vaccine efficacy in human. The subunit vaccine, RTS,S, a chimeric molecule based on a large part of the circumsporozoite (CS) protein, the major surface protein of the sporozoite, fused to the $S$ antigen of the hepatitis $B$ virus, together with a strong adjuvant in the formulation, is the only candidate that has moved to Phase III clinical trials. However its efficacy was at best $\sim 50 \%$ against infection or clinical disease $(32,33)$. So far, only whole-parasite based approaches have repeatedly shown high efficacy (34-36).

\section{MECHANISMS OF IMMUNITY AGAINST THE MALARIA PARASITE}

The parasite has a complex life cycle. Depending on the stage of development in its mammalian host, the parasite can be extracellular or intracellular. The parasite exists in different forms and shapes, possibly expressing different sets of its $\sim 5000$ gene pool (37) at a particular time. The parasite also has different localizations during development, infecting different cell types. Hence, various innate and adaptive immune mechanisms are involved in parasite control and elimination $(38,39)$. Thus, for any vaccine development, it is important to know the protective immune mechanisms to induce.

\section{Immunity to the Pre-Erythrocytic Stage}

During the pre-erythrocytic stage, antibodies can (i) inhibit sporozoite motility in the dermis or in the liver (40), (ii) bind to sporozoite and facilitate phagocytosis by monocytes or macrophages in the spleen or the liver (41), (iii) block sporozoite invasion into hepatocytes by preventing the sporozoite ligand to interact with the hepatocyte receptor(s) (42), and (iv) inhibit sporozoite development inside the hepatocytes (42). Antibodies can also recognize parasite neo-antigens such as heat-shock protein expressed at the surface of infected hepatocytes and induce liver parasite killing through an antibody-dependent cell-mediated mechanism likely involving Kuppfer cells or NK cells (43). The production of high levels of antibodies is dependent of CD4 T cell help, preferably by recognizing (an) epitope(s) present in the sporozoite to facilitate boosting of the antibody during natural infection with the parasite. When the parasite is inside the hepatocytes, it can become the target of CD4 or CD8 T cells (44-46). Hepatocytes express MHC Class I and Class II molecules that can be loaded with parasite antigen-derived epitopes following the TAP or the endosomal pathways (44-47). $\mathrm{T}$ cells kill the parasite either directly or through the action of cytokines, such as IFN- $\gamma$. IFN- $\gamma$ induces the inducible nitric oxide enzyme to produce nitric oxide which directly kills the liver parasites (48-51). Innate immune mechanisms involving type I interferon pathway induced by the parasite infection and active against late schizonts or against reinfection have been recently uncovered (52-54).

\section{Immunity against the Erythrocytic Stage}

Adaptive immunity against the blood stage is more complex than in the liver stage. Merozoite-specific antibodies can (i) prevent 
merozoites from invading RBC alone (55-57) or, in conjunction with complement factors, (ii) prevent merozoite egress from $\mathrm{RBC}$, (iii) agglutinate released merozoites, (iv) promote phagocytosis of merozoites, and (v) facilitate clearance of infected RBC (iRBC) by phagocytic cells through a mechanism called antibody cell-dependent inhibition (ADCI) (58). In ADCI, anti-merozoite cryophilic (IgG1 or IgG3) antibodies bind to merozoites and the immune complexes stimulate phagocytes to release cytokines such as TNF- $\alpha$, which in turn stimulate the phagocytes to produce mediators that lead to the killing of intra-erythrocytic parasites (59, 60). Plasmodium parasites express antigens at the surface of iRBC (61). These antigens are mainly encoded by multigene families such as the var (62), stevor (63), and rifins gene families $(64,65)$ for $P$. falciparum or the pir gene family for $P$. vivax, $P$. knowlesi, and the rodent malaria species (66). The antigens they encoded have been implicated in the cytoadherence phenotype to endothelial cells in deep tissues in order to avoid splenic clearance $(67,68)$. They are also involved in other adhesive phenomena, such as rosetting (the binding of an iRBC to non-infected RBC) (69-72) and agglutination (the binding to iRBC to iRBC through bridging by platelets) $(73,74)$. The cytoadherence abilities of the malaria parasites have been proposed to be responsible for some of the pathologies during malaria infection. Antibodies targeting the surface antigens are thought to act through preventing cytoadherence, promoting iRBC phagocytosis, or iRBC agglutination $(74,75)$.

Antibodies targeting the parasite toxins could also protect from disease. During infection, multiple parasite toxins are released at the time of $i R B C$ rupture. These toxins include the malaria pigment, a by-product of heme degradation by the parasite (76-78), glycophosphatidylinositol (GPI) moieties that are present in many merozoite proteins, a TatD-like DNase (79), a tyrosine-tRNA synthase (80), or lipids extracted from $P$. vivax schizonts (81). Protection from disease by anti-toxins antibodies has been demonstrated experimentally using synthetic glycans mimicking GPI (82).

$\mathrm{T}$ cells are also critical effectors in the immunity against blood-stage malaria infections, despite the lack of $\mathrm{MHC}$ antigens on the surface of iRBC. First and foremost, bloodstage parasite-specific antibodies secreted by $\mathrm{B}$ cells depend on $\mathrm{CD} 4^{+} \mathrm{T}$ helper cells enhancement for optimal production (39). Cytokines released by CD4 $\mathrm{T}$ cells are important for multiplication and maturation of $\mathrm{B}$ cells. The cytokines produced by malaria-specific $\mathrm{T}$ cells influence the isotype of the antibodies produced $(83,84)$ and thus possibly affecting the type of antibody-mediated responses induced. It has been shown that ADCI against $P$. falciparum is mediated by human IgG3 (induced by a Th1 response) and antagonized by IgG2 and IgG4 (induced by a Th2 response) $(59,85)$. Inducing the right isotype is thus important for an antibody-based vaccine. Recent studies have shown that inducing an immune response skewed toward the IgG3 could be achieved through the use of the right adjuvant (86). CD8 T cells were once thought to have only a minimal role in blood-stage immunity $(87,88)$. However, there is now evidence that these cells can inhibit blood-stage infection $(89,90)$. In particular, IFN $\gamma$-secreting CD8 $\mathrm{T}$ cells are important for preventing chronic blood-stage infection in mice (91).

\section{Immunity against the Sexual Stages}

The sexual forms of Plasmodium parasites, gametocytes, are also targets of the immunity against the disease. They are targeted by antibodies which can induce complement-mediated killing of the gametocytes in the host blood $(92,93)$. In the mosquito, antibodies can (i) prevent gamete fusion (94), (ii) induce complementkilling of gametes or ookinetes (95), and (ii) prevent ookinete motility, penetration of the midgut wall and formation of oocyst (96-99). Sexual-stage parasite-specific antibodies depend on CD4 T helper cells for optimal production. However, although antibodies specific for gametes or ookinetes can be produced by vaccination, the humoral immune response cannot be boosted by repeated infections since these forms are not present during infection in the mammalian hosts. Monocytes/macrophages stimulated during infection by the parasites produce cytokines such as TNF- $\alpha$ which in turn stimulates the monocytes/macrophages to produce nitric oxide, a potent inhibitor of gametocytes (100).

\section{MECHANISMS OF IMMUNE EVASION}

To avoid being eliminated by the host immunity, the parasite has developed many escape strategies (Table 1).

\section{EVASION OF THE COMPLEMENT SYSTEM}

The complement system is one of the first innate immune defense mechanisms against pathogens. Many proteins are involved in the activation or the regulation of its lytic activity (101). During the blood-stage, the parasite has developed multiple ways of evading the action of complement. P. falciparum merozoites and iRBC bind to the factor $\mathrm{H}$ ( $\mathrm{fH}$ ), a complement regulator factor, and its alternatively spliced form $\mathrm{fH}$-like protein 1 through its surface molecule Pf92. In the mosquito, gametes bind the $\mathrm{fH}$ through PfGAP50 (102). In both situations, this allows protection against the activation of complement-mediated lysis. In addition, ookinetes express Pfs47, which disrupts the c-Jun $\mathrm{N}$-terminal kinase pathway and prevents mosquito midgut epithelial nitration, making the parasite undetectable by complement system (103).

\section{ANTIBODY-DEPENDENT ENHANCEMENT OF INFECTION}

Antibody-dependent enhancement of infection was first described for viruses (104). Similarly, antibody-dependent enhancement of infection has been described for all stages of parasite development in the mammalian host. It was first reported in the early 1990s that antibodies against the repeat region of the CS protein enhance sporozoite entry and development in hepatocytes for both rodent $(42,43)$ and human parasites (105). Antibodies against the $P$. falciparum asparagine-rich protein enhance merozoite invasion of RBC in vitro (106). Merozoitespecific antibodies in conjunction with complement can also facilitate RBC invasion (107). Antibody-dependent enhancement of infection was also observed in vivo after immunization with a Plasmodium berghei parasite blood-stage preparation 
TABLE 1 | Host immunity and parasite immune escape strategies.

\begin{tabular}{|c|c|c|c|}
\hline Host immunity & Parasite stage & Parasite evasion strategy & Outcome \\
\hline Complement & AS, $S$ & $\begin{array}{l}\text { Bind complement regulatory factor, factor } \mathrm{H} \\
\text { Disrupt c-Jun kinase pathway }\end{array}$ & $\begin{array}{l}\text { Prevent complement activation system } \\
\text { Avoid recognition by complement }\end{array}$ \\
\hline Monocytes/macrophages & AS & $\begin{array}{l}\text { Subvert or kill phagocytes by } \\
\text { (1) inhibiting phagocytosis and } \\
\text { (2) inducing apoptosis }\end{array}$ & $\begin{array}{l}\text { Prevent parasite elimination by } \\
\text { (1) inhibiting phagocyte function and } \\
\text { (2) reducing phagocyte numbers }\end{array}$ \\
\hline Dendritic cells (DC) & AS & $\begin{array}{l}\text { Subvert or kill DC by } \\
\text { (1) inhibiting DC maturation and } \\
\text { (2) engaging apoptosis receptor, Fas }\end{array}$ & $\begin{array}{l}\text { Decrease DC functions by } \\
\text { (1) preventing T cell priming and expansion and } \\
\text { (2) inducing immunosuppression through decreased } \\
\text { pro-inflammatory (IL12) cytokine production and increased } \\
\text { immunosuppressive (IL10) cytokine production }\end{array}$ \\
\hline \multirow[t]{10}{*}{ Antibodies/B cells } & Spz, AS, S & $\begin{array}{l}\text { Antibody enhancement invasion and/or } \\
\text { growth }\end{array}$ & Expansion of parasite in host \\
\hline & Spz, AS, S & Antigen polymorphism & Avoid recognition by antibody \\
\hline & AS & Antigenic variation & Avoid recognition by antibody \\
\hline & AS & Antigenic diversion & Prevent the action of neutralizing antibodies \\
\hline & AS & Epitope masking & Prevent the action of neutralizing antibodies \\
\hline & AS & Smoke-screen strategy & $\begin{array}{l}\text { Avoid antibody recognition by diverting neutralizing antibody from } \\
\text { their target }\end{array}$ \\
\hline & AS & B cell dysregulation & Poor or limited B cell memory \\
\hline & Spz, AS, S & Homology with host proteins & Poor or no antibody response by inducing immunological tolerance \\
\hline & AS & B cell apoptosis & Poor antibody response \\
\hline & AS & Redundancy in cell invasion pathways & $\begin{array}{l}\text { Allow continued invasion and expansion of parasite even when one } \\
\text { invasion pathway is inhibited by antibody }\end{array}$ \\
\hline \multirow[t]{4}{*}{ T cells } & LS & T cell epitope polymorphism & $\begin{array}{l}\text { Avoid T cell recognition prevent } \mathrm{T} \text { cell priming and activity, and } \\
\text { interfere with memory } \mathrm{T} \text { cell development }\end{array}$ \\
\hline & AS & Apoptosis & Poor T cell response \\
\hline & AS & $\begin{array}{l}\text { Induction of expression of check-point } \\
\text { inhibitors }\end{array}$ & Anergy and/or $T$ cell exhaustion \\
\hline & AS & Regulatory $T$ cells & Negative regulation of immune responses \\
\hline Hepatocytes & LS & Cellular shelter & Avoid immune surveillance due to intracellular niche \\
\hline
\end{tabular}

Spz, sporozoite; LS, liver stage; $A S$, asexual blood stage; S, sexual stage.

which led to increased death after challenge (108). In the sexual stage, anti-gamete antibodies were shown to enhance transmission to the mosquito (109).

Antibodies against proteins expressed in one stage of the parasite's development might mediate an enhancement effect in another stage of the parasite's development. This was observed for antibodies against two antigens, the CS protein and heat-shock protein 1 (HSP-1) (110). The CS protein is expressed during sporogony in the mosquito and in the subsequent sporozoite stage. Do Rosario et al. showed that sporozoites generated during sporogony in the presence of anti-CS protein antibodies cannot be inhibited by human polyclonal anti-CS (sporozoite CS) protein (111). HSP70-1 is expressed by the liver stage and the blood stages $(43,110)$. HSP70-1 antibodies have no effect against the blood-stage parasites but they can partially mediate inhibition of liver-stage development through ADCI (43). However, vaccination with a recombinant protein against the $\mathrm{C}$-terminal fragment of HSP70-1 increased the number of gametocytes generated and the subsequent transmission to mosquito (112). Thus, it was proposed that antibodies against the liver-stage parasites can drive merozoites to differentiate into gametocytes and facilitate transmission (112). Immune cross-talk between the different stages of the infection has not been extensively studied beyond the two reports mentioned above. This cross-talk has wider implications. Indeed vaccination against one stage may influence the subsequent stages positively or negatively. For any vaccine against the pre-erythrocytic or blood stages, there will be a need for follow-up studies on the effect on transmission and development of the parasite in the mosquitoes.

\section{ANTIGENIC POLYMORPHISM}

Similar to all other organisms, the parasite is prone to mutation since the replicative machinery is not error free. In its mammalian host, the parasite is haploid and the mutation rate is $\sim 1-0.7 \times 10^{-9}$ mutations per base per generation (113). Since the Plasmodium parasites have a 24 - to 72 -h blood cycle, there is a high probability that mutation can occur and generate different parasite clones. In the mosquito host, the parasite undergoes sexual reproduction where two haploid gametocytes will generate four haploid sporozoite progenies. Recombination does occur in the mosquito stage, and, thus, it will increase the occurrence of gene polymorphism. For some antigens, hundreds of haplotypes have been observed (114). Polymorphism in the coding sequence can be due to point mutations, insertions, or deletions. Interestingly, many Plasmodium antigens possess regions of repeats which can vary in size and number of repetitive units (115). Such diversity is, in most cases, the result of immune pressure since mutations often occur in regions which can be recognized by antibodies or $\mathrm{T}$ cells. Mutations in $\mathrm{B}$ epitopes abolish the recognition of 
parasites by antibodies and may lead to the selection of parasites with a different haplotype. This is important for vaccine development since antibody-based vaccine formulation targeting polymorphic epitopes may either have limited efficacy or select for vaccine-resistant parasite. One such example is the vaccine based on the AMA-1 protein, a highly polymorphic antigen (116-118). However, it is possible to envisage that immunogen(s) inducing broadly inhibitory antibodies recognizing multiple variants may circumvent polymorphism. Studies to identify structural conserved constraints in different variants may pave the way for new vaccines against polymorphic antigens (56).

Polymorphism in T cell epitopes may have profound consequences in $\mathrm{T}$ cell responses and have shown to limit the efficacy of the RTS,S vaccine (119). T cell epitopes are, in general, 8-11 amino acid (aa) and 11-25 aa in length for CD8 T cell and CD4 T cells, respectively (120). After the digestion of parasite protein in the cytoplasm, CD8 antigenic peptides are generated and transported to endoplasmic reticulum by the transporter antigenic peptide protein in the endoplasmic reticulum where they are loaded onto MHC class I molecules and beta 2-microglobulin. CD4 epitopes are generated in endosomes after phagocytosis and protease digestion where they meet MHC class II. PeptideMHC complexes are then expressed in the surface. Exogenous antigens can also be presented by cross-presentation by $\mathrm{MHC}$ class I (121). These complexes can be recognized by the $\mathrm{T}$ cell receptor (122). Mutations in the amino acids that anchor the epitope to the MHC grove can prevent binding of the peptides to the MHC or recognition by the TCR and thus abrogate T cell activity $(123,124)$. This was demonstrated for the CS protein (125). Altered peptide ligand (APL) can still bind to the MHC molecules; however, they prevent $\mathrm{T}$ cell proliferation, no matter if it was used singly or concurrently with a wild-type peptide. They can also prevent cytokine production (126) or change their production pattern, i.e., from IFN- $\gamma$ to the immunosuppressive cytokine interleukin-10 (127). These APL can also interfere with induction of memory $\mathrm{T}$ cells from naïve $\mathrm{T}$ cells (128). This potent mechanism of immune escape is a major hurdle for vaccine development. For any T cell-based vaccine to succeed, a thorough analysis of $\mathrm{T}$ cell polymorphism and their effect should be performed.

\section{ANTIGENIC VARIATION}

Antigenic variation was first described by Neil Brown during $P$. knowlesi chronic relapsing infection in Rhesus monkeys induced by sub-curative drug treatment (129). In an agglutination assay, antibodies produced against different relapse parasite broods agglutinated only schizonts of the immunizing brood but not the other broods. It was further shown that antibodies (130) and spleen could induce antigenic variation in Rhesus monkey infected with a cloned line of P. knowlesi (67) or monkey infected with cloned lines of $P$. falciparum (131). The latter experiments suggested that, contrary to antigenic polymorphism where parasites have different alleles and can be categorized as genomic clones, antigenic variation is a phenotypic variation occurring with the same genomic clone of the parasite. The molecular basis of this phenomenon was elucidated with the sequencing of large segments of the P. falciparum and P. knowlesi genomes and the subsequent complete sequencing of the genome of many Plasmodium species. Antigens prone to antigenic variation are often expressed on the surface of iRBC. Examples includes the multigene family, such the var genes (62), the stevor gene family, the rifin gene family (63), the surfin gene family (132), the sicavar gene family (133), and the Plasmodium interspersed repeats (pir) genes. The var gene family is the most studied and has been shown to be the target of protective anti-blood-stage antibodies (134, 135). It is also involved in many of malaria pathologies due to parasite sequestration resulting from iRBC cytoadherence (136). PfEMP1 proteins, encoded by the var gene family, are highly polymorphic and have different variable domains, called Duffy binding-like domain, which determine their binding specificities to various ligands on endothelial cells such as thrombospondin (137), CD36 (138), ICAM-1/CD54 (139), chondroitin sulfate A (140-142), VCAM-1, E-selectin (143), $\alpha v \beta 3$ integrin (144), hyaluronic acid (145), PECAM-1/CD31 (146), gC1qR/HABP1/p32 (147), or endothelial protein C receptor (148). PfEMP-1 proteins bind also to $\mathrm{RBC}$ through complement receptor 1 to form rosettes (149). P. falciparum parasites possess $\sim 60$ var genes distributed over the 14 chromosomes of the parasite (37). Var genes expression is extremely regulated and only one PfEMP1 type is produced and displayed on the surface of iRBC (150). At each cycle, the parasite switches the expression of the var gene at a rate of $2 \%$ in vitro, generating new clones with new antigenic and adhesive phenotype $(151,152)$. Vir proteins, members of a superfamily of the pir multigene superfamily, also mediate cytoadherence of $P$. vivax $\mathrm{iRBC}$ to endothelial cells (153), resulting to sequestration of mature $\mathrm{iRBC}$ (154). There are 350 vir genes, and they are also highly polymorphic $(155,156)$. Stevor and Rifin proteins are involved in cytoadherence processes and are also highly polymorphic $(70,71)$. In the recent years, it has become clear that some members of these multigene family has a particular role and may be involved in certain pathology. As example, var2CSA mediated the specific cytoadherence of iRBC to placenta (142) and is associated with placental pathology, such as still birth and fetus growth retardation Vaccination using immunogens based on var2CSA will thus induce inhibitory antibodies, preventing cytoadherence $(157,158)$ and placental sequestration. Thus defining the role of members of these multigene families may lead to tailored immune intervention.

\section{ANTIGENIC DIVERSION}

Antigenic diversion occurs when non-inhibitory anti-parasite antibodies prevent the action of inhibitory antibodies. Antigenic diversion has been observed with the merozoite surface protein (MSP)-1. MSP-1 is a surface protein which binds to glycophorin $\mathrm{A}$, a molecule present on the surface of $\mathrm{RBC}$, and thus is essential for merozoite invasion $(159,160)$. MSP-1 is cleaved at the time of invasion. Neutralizing antibodies, which block the proteolytic cleavage in the C-terminal part (MSP-1 ${ }_{19}$ ) of the protein (antibodies), can prevent invasion $(152,161)$. However, antibodies against the adjacent or overlapping region can block the effect of MSP1 $1_{19}$-inhibitory antibodies (blocking antibodies) and thus allowing invasion to occur (162). One possibility to overcome this 
phenomenon is to design immunogen(s) that either induce(s) neutralizing but not blocking antibodies in naïve individuals or tip the balance to greater production of neutralizing antibodies over blocking antibodies in naturally exposed individuals. So far, there has been limited success with MSP-1 (159, 163).

\section{EPITOPE MASKING}

Epitope masking is the capacity of non-parasite-specific antibodies to prevent parasite-specific inhibitory antibodies to react with their epitopes. During the establishment of an antibody response, IgM precedes IgG production and thus are the first line of humoral response either alone or in combination with complement (164). Malaria-specific IgM have been shown to have efficient inhibitory activity against sporozoite and iRBC (165). However, IgM with different specificities can also bind to PfEMP-1 molecules expressed at the surface of iRBC through their Fc portion $(\mathrm{Fc})$ (166). Non-parasite-specific IgM (NpsIgM) promote rosetting and thus may facilitate sequestration, in order to avoid splenic elimination. NpsIgM binding to the PfEMP-1 VARCSA2, which is involved in the binding of $\mathrm{ARBC}$ to chondroitin sulfate in the placenta, appears to protect $\mathrm{iRBC}$ from phagocytosis mediated by IgG (167). NpsIgM also binds to the MSP DBLMSP and DBLMSP2 and prevents IgG binding to these molecules by masking epitopes (168). The role of these two molecules in merozoite biology is still unclear but non-specific IgM epitope masking may be important for protecting the parasite against a specific IgG inhibitory response.

\section{SMOKE-SCREEN STRATEGY BY CROSS-REACTIVITY}

Smoke-screen strategy is often used by the parasite to divert the antibodies specific for one antigen (antigen A, e.g., an epitope of inhibitory antibodies) to react against another antigen (antigen B, e.g., an epitope of non-inhibitory antibodies) which possess regions homologous to antigen A. Antibody reactivity to segments shared by the two proteins will decrease the amount of antibodies reacting to antigen $\mathrm{A}$ and thus reducing efficacy of inhibitory antibodies that can inhibit parasite invasion or development. Many Plasmodium antigens contain repeats, and it was shown that cross-reactivity can occur between different blocks of repeats (169). Cross-reactivity has been observed: (i) between different epitopes from the same block of repeats [i.e., within the same block of repeats in the CS protein, or Ring-erythrocyte surface (RESA), or S-antigen or falciparum interspersed repeat antigen (FIRA)]; (ii) between epitopes present in different blocks of the same antigen (i.e., RESA or FIRA), between repeats of different antigens [between the CS protein and the cross-reactive antigen (CRA), between the histidine-rich proteins]. So far, the importance of this mechanism in the immune response evasion has remained uncertain.

\section{DYSREGULATION OF B CELLS}

Atypical memory B cells are a population of hypo-responsive memory cells which have been first described in chronic HIV infections (170). They increase in numbers during chronic exposure to malaria and are poor responders to antigen restimulation (171). However, they are able to produce neutralizing antibodies (172). These cells might be important during repeated stimulation due to constant exposure and help to control parasite density. However, in regions with lower exposure or in the absence of reinfection, immunity might wane rapidly.

As mentioned in the previous section, many Plasmodium antigens contain repeats. Similar to many viral antigens (173) and haptenated polymers (174), repeats-containing Plasmodium antigens can stimulate B cell independently of T cell help. However, this often leads to the production of mainly IgM and limited B cell memory (175). In addition, exposure to antigens containing repeated motifs can result in the suppression of an ongoing $\mathrm{T}$ cell response $(176,177)$.

\section{HOMOLOGIES WITH HOST PROTEINS}

Many Plasmodium antigens involved in the invasion of host cells have regions which strong homologies with host proteins involved in protein-protein interactions. Thrombospondin type-1 repeat (TSR) domains and von Willebrand factor (vWF)like A domains are present in the CS protein, thrombospondinrelated anonymous protein (TRAP) $(178,179)$, CS protein TRAP-related protein (CTRP) sporozoite surface protein (180), secreted protein with an altered thrombospondin (SPATR) (181), and thrombospondin-related apical merozoite protein (TRAMP) (182). These molecules are involved in different stages of parasite development, in sporozoite and merozoite motility, and in invasion of mosquito midguts, salivary glands, hepatocytes, and RBC. Many merozoite proteins such as MSP-1, MSP-4, MSP-5, MSP-8, and MSP-10 (183), PfRipr (184) and sexual-stage protein, such as P25 or P28 $(185,186)$, have been found to contain an epidermal growth factor domain that is involved in its binding to their receptor. Due to the homology to the host protein, the induction of antibodies to epitopes contained in these homologous regions is difficult since the host is tolerized against its own proteins. Immunization with immunogens containing these motifs with strong adjuvants could possibly escape immunological tolerance but may have the risk of inducing auto-immunity.

\section{IMMUNOSUPPRESSION}

Myeloid cells are essential mediators of an efficient immune response against the malaria parasites. Monocytes, macrophages, and neutrophils phagocytose $\mathrm{iRBC}$, which eventually leads to the elimination of the parasites (187). Phagocytosis by monocytes/ macrophages can be mediated through the interactions of PfEMP-1 and CD36 without inducing or increasing a protective pro-inflammatory response (188). However, during infection, phagocyte functions can be diminished after the ingestion of the malaria pigment or hemozoin (the digested product of hemoglobin by the parasites) $(189,190)$. Pigment-loaded macrophages cannot phagocytose more iRBC, and their capacity to generate radical oxygen intermediates is also reduced (191).

Dendritic cells (DCs) are essential to induce adaptive immune responses (192). Engagement of CD36 and CD51 (the $\alpha \mathrm{v}$ integrin 
chain) on DCs by PfEMP-1-expressing parasites impair DC maturation and its capacity to prime $\mathrm{T}$ cell responses, leading to reduced production of pro-inflammatory cytokines such as IL-12 and increased production of immunosuppressive cytokines such as IL-10 (193).

Acute blood-stage infection induces a strong activation of mononuclear cells. This can result in apoptosis in monocytes, B cells, T cells, and DCs (194-199). Acute infection can also lead to thymus apoptosis and depletion, thereby diminishing the output of new naïve T cells (200). On the other hand, chronically activated T cells (both $\alpha \beta$ and $\gamma \delta$ ) during lingering blood infection or multiple reinfections can also enter a phase of anergy (201-203) and/ or exhaustion (204). Plasmodium infection activates check-point inhibitors molecules such as program cell death protein 1 (PD-1), program death ligand 1 (PD-L1), PD-L2, lymphocyte-activation gene 3 (LAG-3), and cytotoxic T lymphocyte antigen-4 (CTLA-4) in CD4 and CD8 T cells. In rodent models, blockade of these molecules facilitates the elimination of blood parasites (91, 205, 206) and the establishment of T cell memory (207). Regulatory $\mathrm{T}$ cells often expand during infection (208). Their principal role is to control the excessive pro-inflammatory response which depending on the parasite species may be beneficial or detrimental (209-211). Taken together, these mechanisms leading to immunosuppression are likely to favor survival of the parasite in the host and prevent the establishment of an efficient memory response. In addition, while it might also be beneficial for the host to prevent immunopathogenesis (212), ensuring host survival is advantageous to parasite survival.

\section{REDUNDANT PATHWAYS OF RED BLOOD CELL INVASION}

Invasion of RBC by merozoites is a complex process. It involves a precise and coordinated expression of different sets of proteins which are either expressed on the surface of the merozoite or in the organelles such as rhoptries, micronemes, and dense granules located at the apical end of the merozoite (183). The invasion process has been amply studied for $P$. falciparum. It was shown that the parasites can use multiple pathways involving at least nine ligand/receptor combinations to invade a RBC. There are two parasite protein families involved in the host-cell selection and invasion process; the reticulocyte-binding protein homologs (Rh) and the erythrocyte binding-like proteins (EBL) (213). These proteins are polymorphic, and their expression varies depending on parasite clones. Polymorphisms in a $P$. falciparum EBL have been shown to result in a change in their receptor specificity (214) or in a switch to Rh-dependent invasion, a different invasion pathway for RBC invasion (215). Variation in the use of erythrocyte invasion pathways results in evasion of human inhibitory antibodies (216). Thus, this suggests that vaccines targeting only one pathway will select parasite using other pathways. However, so far, the pathway involving Rh5 and its ligand Basigin/CD147 has been shown to be required for all parasites clones and isolates tested so far and has shown limited polymorphism (217). It thus represents a promising vaccine candidate $(218,219)$.

Contrary to $P$. falciparum, $P$. vivax was thought to use only one pathway to invade RBC (220). P. vivax merozoites only invade reticulocytes, the immature RBC. Since people in West Africa or with West African origins naturally lack the Duffy antigen, they are resistant to $P$. vivax blood infection $(221,222)$. This serves as a strong argument for the existence of only one invasion pathway for $P$. vivax. However, in the recent years, many studies have reported $P$. vivax infections in Duffy-negative patients (220, 222-228), suggesting that $P$. vivax merozoites may use another pathway to invade reticulocytes (229). This may limit the efficacy of vaccine based on the Duffy-binding protein, the ligand of the Duffy antigen (230), by selecting for parasites that are able to invade via this alternative pathway.

\section{SHELTERS}

Infection with sporozoites from some human/primate parasites, such as $P$. vivax, $P$. ovale, $P$. cynomolgi, Plasmodium simiovale, and Plasmodium fieldi, may lead to relapse (231). After a patent blood infection is completely cleared by the immune system or by drug treatment, blood parasites may reappear and induce new clinical attacks (232). This new infection originates from long-lasting liver forms, called hypnozoites (233). These non-dividing and metabolically active forms (234) can persist in the liver of their infected hosts for long period of time. Histological analysis on liver from infected rhesus monkeys did not show any signs of cellular immune responses against hypnozoites or late-developing schizonts originating from these forms $(235,236)$. This suggests that hypnozoites do not trigger any immune response, and do not lead to the expression of MHC molecules containing parasitesderived peptides. Due to the difficulty in studying these forms in vitro and in vivo (237), the mechanisms by which the parasite subverts immune recognition is unknown. Vaccine development against the pre-erythrocytic of $P$. vivax has been limited, and formulations targeting the liver forms may not work against the hypnozoites.

As mentioned above, during primary sporozoite-induced infection in natural hosts, no cellular immune responses are observed $(8,238-240)$. The liver is rich in macrophages and Kupffer cells, which can phagocytose emerging hepatic merozoites. To avoid being recognized by phagocytes, merozoites are released inside vesicles called merosomes in to the sinusoid lumen. Merosomes do not express macrophage-recognition signal such as phosphatidyl-serine and thus escape being phagocytosed (8). Merosomes are carried to the lung vasculature where blood circulation is low (241) before releasing their merozoite cargo (242).

Vesicles containing merozoites have been observed inside other cell types other than RBC, such as platelets (243), in macrophages (244), and in DCs $(245,246)$. It has been shown that merozoites can also divide in the DCs expressing CD317/ tetherin, and eventually initiate new infections (245). It is not yet known how the phagocytosed parasites evade digestion or if a population of merozoites can infect and multiply in these cells. Free merozoite-containing vesicles, called merophores, have also been observed in the lymph circulation during rodent malaria infection $(247,248)$. This could explain recrudescence or latency of infection. However, as for the merosomes, these vesicles may be devoid of recognition signals for phagocyte uptake and may not express parasite antigens on their surface. 


\section{CONCLUSION}

Malaria parasites have been interacting with its mammalian hosts for more than 150 million years (249) and have efficiently evolved to survive under the pressure of the host immune system. The parasite has developed numerous immune evasion mechanisms. Since new host immune mechanisms against the parasite are constantly being discovered, it will be of no surprise that new immune escape mechanisms by the parasite will be uncovered. For example, there is still little known on how innate immunity are induced during infection and on how protective epitopes are generated. The ultimate goal of understanding the immune responses to the malaria parasites is the development of vaccines. The selection of antigens and delivery system is governed by the target. Historically, before the whole genome was sequenced, the first malarial antigens, that were cloned and sequenced, have been assumed to be good vaccine candidates (250). However, all these antigens are immunodominant and are involved in immune escape. For vaccines to develop in a timely manner, the selection criteria should involve a more stringent GO-NO Go selection based on the analysis of the potential of

\section{REFERENCES}

1. Millar SB, Cox-Singh J. Human infections with Plasmodium knowlesi zoonotic malaria. Clin Microbiol Infect (2015) 21:640-8. doi:10.1016/j. cmi.2015.03.017

2. Ta TH, Hisam S, Lanza M, Jiram AI, Ismail N, Rubio JM. First case of a naturally acquired human infection with Plasmodium cynomolgi. Malar J (2014) 13:68. doi:10.1186/1475-2875-13-68

3. World Health Organisation. World Malaria Report. Geneva: World Health Organisation (2015).

4. Amino R, Thiberge S, Martin B, Celli S, Shorte S, Frischknecht F, et al. Quantitative imaging of Plasmodium transmission from mosquito to mammal. Nat Med (2006) 12:220-4. doi:10.1038/nm1350

5. Amino R, Giovannini D, Thiberge S, Gueirard P, Boisson B, Dubremetz JF, et al. Host cell traversal is important for progression of the malaria parasite through the dermis to the liver. Cell Host Microbe (2008) 3:88-96. doi:10.1016/j.chom.2007.12.007

6. Mota MM, Pradel G, Vanderberg JP, Hafalla JCR, Frevert U, Nussenzweig RS, et al. Migration of Plasmodium sporozoites through cells before infection. Science (2001) 291:141-4. doi:10.1126/science.291.5501.141

7. Tavares J, Formaglio P, Thiberge S, Mordelet E, van Rooijen N, Medvinsky A, et al. Role of host cell traversal by the malaria sporozoite during liver infection. J Exp Med (2013) 210:905-15. doi:10.1084/jem.20121130

8. Sturm A, Amino R, Van De Sand C, Regen T, Retzlaff S, Rennenberg A, et al. Manipulation of host hepatocytes by the malaria parasite for delivery into liver sinusoids. Science (2006) 313:1287-90. doi:10.1126/science.1115257

9. White NJ, Pukrittayakamee S, Hien TT, Faiz MA, Mokuolu OA, Dondorp AM. Malaria. Lancet (2013) 383:7223. doi:10.1016/S0140-6736(13)60024-0

10. Pathak VA, Ghosh K. Erythropoiesis in malaria infections and factors modifying the erythropoietic response. Anemia (2016) 2016:9310905. doi:10.1155/2016/9310905

11. Storm J, Craig AG. Pathogenesis of cerebral malaria-inflammation and cytoadherence. Front Cell Infect Microbiol (2014) 4:100. doi:10.3389/fcimb

12. Haldar K, Murphy SC, Milner DA, Taylor TE. Malaria: mechanisms of erythrocytic infection and pathological correlates of severe disease. Annu Rev Pathol (2007) 2:217-49. doi:10.1146/annurev.pathol.2.010506. 091913

13. Milner DA Jr, Whitten RO, Kamiza S, Carr R, Liomba G, Dzamalala C, et al. The systemic pathology of cerebral malaria in African children. Front Cell Infect Microbiol (2014) 4:104. doi:10.3389/fcimb.2014.00104

14. Kanyuka M, Ndawala J, Mleme T, Chisesa L, Makwemba M, Amouzou A, et al. Malawi and millennium development goal 4: a countdown to 2015 the vaccine candidate to avoid immune escape. This also calls for an immunological approach to define correlates of protection to guide vaccine development. The development of the experimental human malarial challenge model, where complete sterile protection can be obtained $(34,35)$, is strong evidence that a vaccine against malaria can be obtained. Together with parasite genetics, the development of the rodent models and the experimental human challenge model would greatly assist in making the critical GO-NO Go decisions and facilitate the development of an efficacious vaccine against malaria in the foreseeable future.

\section{AUTHOR CONTRIBUTIONS}

Both the authors listed have made substantial, direct, and intellectual contribution to the work and approved it for publication.

\section{FUNDING}

This work was supported by an intramural grant from Singapore's Agency for Science, Technology and Research.

country case study. Lancet Glob Health (2016) 4:e201-2124. doi:10.1016/ S2214-109X(15)00294-6

15. Dondorp AM, Yeung S, White L, Nguon C, Day NP, Socheat D, et al. Artemisinin resistance: current status and scenarios for containment. Nat Rev Microbiol (2010) 8:272-80. doi:10.1038/nrmicro2331

16. White LJ, Flegg JA, Phyo AP, Wiladpai-Ngern JH, Bethell D, Plowe CV, et al. Defining the in vivo phenotype of artemisinin-resistant falciparum malaria: a modelling approach. PLoS Med (2015) 12:e1001823. doi:10.1371/journal. pmed.1001823

17. Canavati SE, Lawford HL, Fatunmbi BS, Lek D, Top-Samphor N, Leang R, et al. Establishing research priorities for malaria elimination in the context of the emergency response to artemisinin resistance framework-the Cambodian approach. Malar J (2016) 15:120. doi:10.1186/s12936-0161117-9

18. von Seidlein LV, Dondorp AM. Fighting fire with fire: mass antimalarial drug administrations in an era of antimalarial resistance. Expert Rev Anti Infect Ther (2015) 13:715-30. doi:10.1586/14787210.2015.1031744

19. White NJ, Pukrittayakamee S, Phyo AP, Rueangweerayut R, Nosten F, Jittamala P, et al. Spiroindolone KAE609 for falciparum and vivax malaria. N Engl J Med (2014) 371:403-10. doi:10.1056/NEJMoa1315860

20. Rottmann M, McNamara C, Yeung BK, Lee MC, Zou B, Russell BM, et al. Spiroindolones, a potent compound class for the treatment of malaria. Science (2010) 329:1175-80. doi:10.1126/science.1193225

21. White NJ, Duong TT, Uthaisin C, Nosten F, Phyo AP, Hanboonkunupakarn B, et al. Antimalarial activity of KAF156 in falciparum and vivax malaria. N Engl J Med (2016) 375:1152-60. doi:10.1056/NEJMoa1602250

22. McNamara CW, Lee MC, Lim CS, Lim SH, Roland J, Nagle A, et al. Targeting Plasmodium PI(4)K to eliminate malaria. Nature (2013) 504:248-53. doi:10.1038/nature1278

23. Celli A, Santori FS. Intorno alla siero-profilassi della malaria. 1a comunicazione. Annali d'Igiene Sperimentale (1897) 7:183-90.

24. McGregor IA. Malarial immunity: current trends and prospects. Ann Trop Med Parasitol (1987) 81:647-56.

25. Sergent E, Parrot L. L'immunite, la premunition et la resistance. Ann Inst Pasteur Algers (1935) 13:279-315.

26. Sergent E. Sur l'immunite dans le paludisme des oiseaux. Conservation in vitro des sporozoites de Plasmodium relictum. Immunite relative obtenue par inoculation de ces sporozoites. C R Acad Sci (1910) 151:407-9.

27. Heidelberger M, Mayer MM, Alving AS, Craige BJ, Jones R Jr, Pullman TN, et al. Studies in human malaria. IV. An attempt at vaccination of volunteers against mosquito-borne infection with Plasmodium vivax. J Immunol (1946) $53: 113-8$. 
28. Heidelberger M, Mayer MM, Demarest CR. Studies in human malaria. I. The preparation of vaccines and suspensions containing plasmodia. J Immunol (1946) 52:325-30.

29. Freund J, Sommer HE, Walter AW. Immunization against malaria: vaccination of ducks with killed parasites incorporated with adjuvants. Science (1945) 102:200-2. doi:10.1126/science.102.2643.200

30. Freund J, Thomson KJ, Sommer HE, Walter AW, Schenkein EL. Immunization of rhesus monkeys against malarial infection (P. knowlesi) with killed parasites and adjuvants. Science (1945) 102:202-4. doi:10.1126/science. 102.2643.202

31. Halbroth BR, Draper SJ. Recent developments in malaria vaccinology. $A d v$ Parasitol (2015) 88:1-49. doi:10.1016/bs.apar.2015.03.001

32. Kaslow DC, Biernaux S. RTS,S: toward a first landmark on the malaria vaccine technology roadmap. Vaccine (2015) 33:7425-32. doi:10.1016/j

33. Olotu A, Fegan G, Wambua J, Nyangweso G, Awuondo KO, Leach A, et al. Four-year efficacy of RTS,S/AS01E and its interaction with malaria exposure. N Engl J Med (2013) 368:1111-20. doi:10.1056/NEJMoa1207564

34. Roestenberg M, McCall M, Hopman J, Wiersma J, Luty AJF, van Gemert GJ, et al. Protection against a malaria challenge by sporozoite inoculation. $N$ Engl J Med (2009) 361:468-77. doi:10.1056/NEJMoa0805832

35. Seder RA, Chang LJ, Enama ME, Zephir KL, Sarwar UN, Gordon IJ, et al. Protection against malaria by intravenous immunization with a nonreplicating sporozoite vaccine. Science (2013) 341:1359-65. doi:10.1126/ science. 1241800

36. Ishizuka AS, Lyke KE, DeZure A, Berry AA, Richie TL, Mendoza FH, et al. Protection against malaria at 1 year and immune correlates following PfSPZ vaccination. Nat Med (2016) 22:614-23. doi:10.1038/nm.4110

37. Gardner MJ, Hall N, Fung E, White O, Berriman M, Hyman RW, et al. Genome sequence of the human malaria parasite Plasmodium falciparum. Nature (2002) 419:498-511. doi:10.1038/nature01097

38. Stevenson MM, Riley EM. Innate immunity to malaria. Nat Rev Immunol (2004) 4:169-80. doi:10.1038/nri1311

39. Langhorne J, Ndungu FM, Sponaas AM, Marsh K. Immunity to malaria: more questions than answers. Nat Immunol (2008) 9:725-32. doi:10.1038/ ni.f. 205

40. Vanderberg JP, Frevert U. Intravital microscopy demonstrating antibodymediated immobilisation of Plasmodium berghei sporozoites injected into skin by mosquitoes. Int J Parasitol (2004) 34:991-6. doi:10.1016/j. ijpara.2004.05.005

41. Schwenk R, Lumsden JM, Rein LE, Juompan L, Kester KE, Heppner DG Jr, et al. Immunization with the RTS,S/AS malaria vaccine induces IFNgamma+ CD4 T cells that recognize only discrete regions of the circumsporozoite protein and these specificities are maintained following booster immunizations and challenge. Vaccine (2011) 29:8846-54. doi:10.1016/j. vaccine.2011.09.098

42. Nudelman S, Renia L, Charoenvit Y, Yuan L, Miltgen F, Beaudoin RL, et al. Dual action of anti-sporozoite antibodies in vitro. J Immunol (1989) 143:996-1000.

43. Renia L, Mattei DM, Goma J, Pied S, Dubois P, Miltgen F, et al. A malaria heat-shock-like determinant expressed on the infected hepatocyte surface is the target of antibody-dependent cell-mediated cytotoxic mechanisms by nonparenchymal liver cells. Eur J Immunol (1990) 20:1445-9. doi:10.1002/ eji.1830200706

44. Renia L, Marussig MS, Grillot D, Pied S, Corradin G, Miltgen F, et al. In vitro activity of $\mathrm{CD} 4+$ and $\mathrm{CD} 8+\mathrm{T}$ lymphocytes from mice immunized with a synthetic malaria peptide. Proc Natl Acad Sci U S A (1991) 88:7963-7. doi:10.1073/pnas.88.18.7963

45. Renia L, Grillot DA, Marussig M, Corradin G, Miltgen F, Lambert PH, et al. Effector functions of circumsporozoite peptide-primed $\mathrm{CD} 4^{+} \mathrm{T}$ cell clones against Plasmodium yoelii liver stages. J Immunol (1993) 150:1471-8.

46. Bongfen SE, Torgler R, Romero JF, Renia L, Corradin G. Plasmodium berghei-infected primary hepatocytes process and present the circumsporozoite protein to specific CD8+ T cells in vitro. J Immunol (2007) 178:7054-63. doi:10.4049/jimmunol.178.11.7054

47. Pichugin A, Steers N, De la Vega P, Zarling S, Chalom I, Krzych U. TAPmediated processing of exoerythrocytic antigens is essential for protection induced with radiation-attenuated Plasmodium sporozoites. Eur J Immunol (2016) 46:885-96. doi:10.1002/eji.201545748
48. Mellouk S, Hoffman SL, Liu ZZ, de la Vega P, Billiar TR, Nussler AK. Nitric oxide-mediated antiplasmodial activity in human and murine hepatocytes induced by gamma interferon and the parasite itself: enhancement by exogenous tetrahydrobiopterin. Infect Immun (1994) 62:4043-6.

49. Nussler AK, Renia L, Pasquetto V, Miltgen F, Matile H, Mazier D. In vivo induction of the nitric oxide pathway in hepatocytes after injection with irradiated malaria sporozoites, malaria blood parasites or adjuvants. Eur J Immunol (1993) 23:882-7. doi:10.1002/eji.1830230417

50. Seguin MC, Klotz FW, Schneider I, Weir JP, Goodbary M, Slayter M, et al. Induction of nitric oxide synthase protects against malaria in mice exposed to irradiated Plasmodium berghei infected mosquitoes: involvement of interferon-gamma and CD8+ T cells. J Exp Med (1994) 180:353-8. doi:10.1084/ jem.180.1.353

51. Cockburn IA, Amino R, Kelemen RK, Kuo SC, Tse SW, Radtke A, et al. In vivo imaging of $\mathrm{CD} 8+\mathrm{T}$ cell-mediated elimination of malaria liver stages. Proc Natl Acad Sci U S A (2013) 110:9090-5. doi:10.1073/pnas.1303858110

52. Liehl P, Meireles P, Albuquerque IS, Pinkevych M, Baptista F, Mota MM, et al. Innate immunity induced by Plasmodium liver infection inhibits malaria reinfections. Infect Immun (2015) 83:1172-80. doi:10.1128/IAI.02796-14

53. Liehl P, Zuzarte-Luis V, Chan J, Zillinger T, Baptista F, Carapau D, et al. Hostcell sensors for Plasmodium activate innate immunity against liver-stage infection. Nat Med (2013) 20:47-53. doi:10.1038/nm.3424

54. Miller JL, Sack BK, Baldwin M, Vaughan AM, Kappe SH. Interferonmediated innate immune responses against malaria parasite liver stages. Cell Rep (2014) 7:436-47. doi:10.1016/j.celrep.2014.03.018

55. Reiling L, Richards JS, Fowkes FJ, Barry AE, Triglia T, Chokejindachai W, et al. Evidence that the erythrocyte invasion ligand PfRh2 is a target of protective immunity against Plasmodium falciparum malaria. J Immunol (2010) 185:6157-67. doi:10.4049/jimmunol.1001555

56. Dutta S, Lee SY, Batchelor AH, Lanar DE. Structural basis of antigenic escape of a malaria vaccine candidate. Proc Natl Acad Sci U S A (2007) 104:12488-93. doi:10.1073/pnas.0701464104

57. Jiang L, Gaur D, Mu J, Zhou H, Long CA, Miller LH. Evidence for erythrocyte-binding antigen 175 as a component of a ligand-blocking blood-stage malaria vaccine. Proc Natl Acad Sci USA (2011) 108:7553-8. doi:10.1073/pnas.1104050108

58. Marsh K, Kinyanjui SM. Immune effector mechanisms in malaria. Parasite Immunol (2006) 28:51-60. doi:10.1111/j.1365-3024.2006.00808.x

59. Bouharoun-Tayoun H, Attanath P, Sabchareon A, Chongsuphajaisiddhi T, Druilhe P. Antibodies that protect humans against Plasmodium falciparum blood stages do not on their own inhibit parasite growth and invasion in vitro, but act in cooperation with monocytes. JExp Med (1990) 172:1633-41. doi:10.1084/jem.172.6.1633

60. Bouharoun-Tayoun H, Oeuvray C, Lunel F, Druilhe P. Mechanisms underlying the monocyte-mediated antibody-dependent killing of Plasmodium falciparum asexual blood stages. J Exp Med (1995) 182:409-18. doi:10.1084/ jem.182.2.409

61. Frech C, Chen N. Variant surface antigens of malaria parasites: functional and evolutionary insights from comparative gene family classification and analysis. BMC Genomics (2013) 14:427. doi:10.1186/1471-2164-14-427

62. Su XZ, Heatwole VM, Wertheimer SP, Guinet F, Herrfeldt JA, Peterson DS, et al. The large diverse gene family var encodes proteins involved in cytoadherence and antigenic variation of Plasmodium falciparuminfected erythrocytes. Cell (1995) 82:89-100. doi:10.1016/0092-8674(95) 90055-1

63. Cheng Q, Cloonan N, Fischer K, Thompson J, Waine GJ, Lanzer MP, et al. Stevor and rif are Plasmodium falciparum multicopy gene families which potentially encode variant antigens. Mol Biochem Parasitol (1998) 97:161-76. doi:10.1016/S0166-6851(98)00144-3

64. Wang CW, Hviid L. Rifins, rosetting, and red blood cells. Trends Parasitol (2015) 31:285-6. doi:10.1016/j.pt.2015.04.009

65. Kyes SA, Rowe JA, Kriek N, Newbold CI. Rifins: a second family of clonally variant proteins expressed on the surface of red cells infected with Plasmodium falciparum. Proc Natl Acad Sci U S A (1999) 96:9333-8. doi:10.1073/pnas.96.16.9333

66. Janssen CS, Phillips RS, Turner CM, Barrett MP. Plasmodium interspersed repeats: the major multigene superfamily of malaria parasites. Nucleic Acids Res (2004) 32:5712-20. doi:10.1093/nar/gkh907 
67. Barnwell JW, Howard RJ, Coon HG, Miller LH. Splenic requirement for antigenic variation and expression of the variant antigen on the erythrocyte membrane in cloned Plasmodium knowlesi malaria. Infect Immun (1983) 40:985-94.

68. David PH, Hommel M, Miller LH, Udeinya IJ, Oligino LD. Parasite sequestration in Plasmodium falciparum malaria: spleen and antibody modulation of cytoadherence of infected erythrocytes. Proc Natl Acad Sci U S A (1983) 80:5075-9. doi:10.1073/pnas.80.16.5075

69. Udomsangpetch R, Wahlin B, Carlson J, Berzins K, Torii M, Aikawa M, et al. Plasmodium falciparum-infected erythrocytes form spontaneous erythrocytes rosettes. J Exp Med (1987) 169:1835-40. doi:10.1084/jem.169. 5.1835

70. Niang M, Yan YX, Preiser PR. The Plasmodium falciparum STEVOR multigene family mediates antigenic variation of the infected erythrocyte. PLoS Pathog (2009) 5:e1000307. doi:10.1371/annotation/c58250db-8cce40c5-b7ac-42204050069a

71. Goel S, Palmkvist M, Moll K, Joannin N, Lara P, Akhouri R, et al. RIFINs are adhesins implicated in severe Plasmodium falciparum malaria. Nat Med (2015) 21:314-7. doi:10.1038/nm.3812

72. Lee WC, Malleret B, Lau YL, Mauduit M, Fong MY, Cho JS, et al. Glycophorin $\mathrm{C}$ (CD236R) mediates vivax malaria parasite rosetting to normocytes. Blood (2014) 123:e100-9. doi:10.1182/blood-2013-12-541

73. Pain A, Ferguson DJP, Kai O, Urban BC, Lowe B, Marsh K, et al. Plateletmediated clumping of Plasmodium falciparum-infected erythrocytes is a common adhesive phenotype and is associated with severe malaria. Proc Natl Acad Sci U S A (2001) 98:1805-10. doi:10.1073/pnas.98.4.1805

74. Tan J, Pieper K, Piccoli L, Abdi A, Foglierini M, Geiger R, et al. A LAIR1 insertion generates broadly reactive antibodies against malaria variant antigens. Nature (2016) 529:105-9. doi:10.1038/nature16450

75. Chan JA, Fowkes FJ, Beeson JG. Surface antigens of Plasmodium falciparum-infected erythrocytes as immune targets and malaria vaccine candidates. Cell Mol Life Sci (2014) 71:3633-57. doi:10.1007/s00018-0141614-3

76. Olivier M, Van Den Ham KM, Shio MT, Kassa FA, Fougeray S. Malarial pigment hemozoin and the innate inflammatory response. Front Immunol (2014) 5:25. doi:10.3389/fimmu.2014.00025

77. Corbett Y, Parapini S, D’Alessandro S, Scaccabarozzi D, Rocha BC, Egan TJ, et al. Involvement of Nod2 in the innate immune response elicited by malarial pigment hemozoin. Microbes Infect (2015) 17:184-94. doi:10.1016/j. micinf.2014.11.001

78. Boura M, Frita R, Gois A, Carvalho T, Hanscheid T. The hemozoin conundrum: is malaria pigment immune-activating, inhibiting, or simply a bystander? Trends Parasitol (2013) 29:469-76. doi:10.1016/j.pt.2013.07.005

79. Chang Z, Jiang N, Zhang Y, Lu H, Yin J, Wahlgren M, et al. The TatD-like DNase of Plasmodium is a virulence factor and a potential malaria vaccine candidate. Nat Commun (2016) 7:11537. doi:10.1038/ncomms11537

80. Bhatt TK, Khan S, Dwivedi VP, Banday MM, Sharma A, Chandele A, et al. Malaria parasite tyrosyl-tRNA synthetase secretion triggers pro-inflammatory responses. Nat Commun (2011) 2:530. doi:10.1038/ncomms1522

81. Wijesekera SK, Carter RL, Rathnayaka L, Mendis KN. A malaria parasite toxin associated with Plasmodium vivax paroxysms. Clin Exp Immunol (1996) 104:221-7. doi:10.1046/j.1365-2249.1996.07699.x

82. Schofield L, Hewitt MC, Evans K, Siomos MA, Seeberger PH. Synthetic GPI as a candidate anti-toxic vaccine in a model of malaria. Nature (2002) 418:785-9. doi:10.1038/nature00937

83. von der Weid T, Kopf MA, Kohler G, Langhorne J. The immune response to Plasmodium chabaudi malaria in interleukin-4-deficient mice. Eur J Immunol (1994) 24:2285-93. doi:10.1002/eji.1830241004

84. Seixas EM, Fonseca L, Langhorne J. The influence of gammadelta T cells on the $\mathrm{CD} 4+\mathrm{T}$ cell and antibody response during a primary Plasmodium chabaudi chabaudi infection in mice. Parasite Immunol (2002) 24:131-40. doi:10.1046/j.1365-3024.2002.00446.x

85. Bouharoun-Tayoun H, Druilhe P. Plasmodium falciparum malaria: evidence for an isotype imbalance which may be responsible for delayed acquisition of protective immunity. Infect Immun (1992) 60:1473-81.

86. Chitnis CE, Mukherjee P, Mehta S, Yazdani SS, Dhawan S, Shakri AR, et al. Phase I clinical trial of a recombinant blood stage vaccine candidate for Plasmodium falciparum malaria based on MSP1 and EBA175. PLoS One (2015) 10:e0117820. doi:10.1371/journal.pone.0137816
87. Suss G, Eichmann K, Kury E, Linke A, Langhorne J. Roles of CD4 and CD8 bearing $\mathrm{T}$ lymphocytes in the immune response to the erythrocytic stages of Plasmodium chabaudi. Infect Immun (1988) 56:3081-8.

88. Podoba JE, Stevenson MM. CD4+ and CD8+ T lymphocytes both contribute to acquired immunity to blood-stage Plasmodium chabaudi AS. Infect Immun (1991) 59:51-8.

89. Imai $\mathrm{T}$, Ishida $\mathrm{H}$, Suzue $\mathrm{K}$, Taniguchi $\mathrm{T}$, Okada $\mathrm{H}$, Shimokawa $\mathrm{C}$, et al. Cytotoxic activities of CD8+ T cells collaborate with macrophages to protect against blood-stage murine malaria. Elife (2015) 4:e04232. doi:10.7554/ eLife.04232

90. Imai T, Shen J, Chou B, Duan X, Tu L, Tetsutani K, et al. Involvement of $\mathrm{CD} 8+\mathrm{T}$ cells in protective immunity against murine blood-stage infection with Plasmodium yoelii 17XL strain. Eur J Immunol (2010) 40:1053-61. doi:10.1002/eji.200939525

91. Horne-Debets JM, Faleiro R, Karunarathne DS, Liu XQ, Lineburg KE, Poh CM, et al. PD-1 dependent exhaustion of CD8 T cells drives chronic malaria. Cell Rep (2013) 5:1204-13. doi:10.1038/srep26210

92. Read D, Lensen AHW, Begarnie S, Haley S, Raza A, Carter RL. Transmission-blocking antibodies against multiple, non-variant target epitopes of the Plasmodium falciparum gamete surface antigen Pfs 230 are all complement-fixing. Parasite Immunol (1994) 16:511-9. doi:10.111 1/j.1365-3024.1994.tb00305.x

93. Margos G, Navarette S, Butcher GA, Davies A, Willers C, Sinden RE, et al. Interaction between host complement and mosquito-midgut-stage Plasmodium berghei. Infect Immun (2001) 69:5064-71. doi:10.1128/ IAI.69.8.5064-5071.2001

94. Blagborough AM, Sinden RE. Plasmodium berghei HAP2 induces strong malaria transmission-blocking immunity in vivo and in vitro. Vaccine (2009) 27:5187-94. doi:10.1016/j.vaccine.2009.06.069

95. Volohonsky G, Steinert S, Levashina EA. Focusing on complement in the antiparasitic defense of mosquitoes. Trends Parasitol (2010) 26:1-3. doi:10.1016/j.pt.2009.10.003

96. Sieber KP, Huber M, Kaslow DC, Banks SM, Torii M, Aikawa M, et al. The peritrophic membrane as a barrier: its penetration by Plasmodium gallinaceum and the effect of a monoclonal antibody to ookinetes. Exp Parasitol (1991) 72:145-56. doi:10.1016/0014-4894(91)90132-G

97. Duffy PE, Pimenta P, Kaslow DC. Pgs28 belongs to a family of epidermal growth factor-like antigens that are targets of malaria transmissionblocking antibodies. JExp Med (1993) 177:505-10. doi:10.1084/jem. 177.2.505

98. Ranawaka GR, Fleck SL, Blanco AR, Sinden RE. Characterization of the modes of action of anti-Pbs21 malaria transmission-blocking immunity: ookinete to oocyst differentiation in vivo. Parasitology (1994) 109:403-11. doi:10.1017/S0031182000080653

99. Baton LA, Ranford-Cartwright LC. Do malaria ookinete surface proteins P25 and P28 mediate parasite entry into mosquito midgut epithelial cells? Malar $J$ (2005) 4:15. doi:10.1186/1475-2875-4-15

100. Naotunne TS, Karunaweera ND, Mendis KN, Carter RL. Cytokine-mediated inactivation of malarial gametocytes is dependent on the presence of white blood cells and involves reactive nitrogen intermediates. Immunology (1993) 78:555-62.

101. Dunkelberger JR, Song WC. Complement and its role in innate and adaptive immune responses. Cell Res (2010) 20:34-50. doi:10.1038/cr.2009.139

102. Simon N, Lasonder E, Scheuermayer M, Kuehn A, Tews S, Fischer R, et al. Malaria parasites co-opt human factor $\mathrm{H}$ to prevent complementmediated lysis in the mosquito midgut. Cell Host Microbe (2013) 13:29-41. doi:10.1016/j.chom.2012.11.013

103. Ramphul UN, Garver LS, Molina-Cruz A, Canepa GE, Barillas-Mury C. Plasmodium falciparum evades mosquito immunity by disrupting JNKmediated apoptosis of invaded midgut cells. Proc Natl Acad Sci U S A (2015) 112:1273-80. doi:10.1073/pnas.1423586112

104. Morens DM. Antibody-dependent enhancement of infection and the pathogenesis of viral disease. Clin Infect Dis (1994) 19:500-12. doi:10.1093/ clinids/19.3.500

105. Hollingdale MR, Appiah A, Leland P, Do Rosario VE, Mazier D, Pied S, et al. Activity of human volunteer sera to candidate Plasmodium falciparum circumsporozoite vaccines in the inhibition of sporozoite invasion (ISI) of human hepatoma cells and hepatocytes assays. Trans $R$ Soc Trop Med Hyg (1990) 84:325-9. doi:10.1016/0035-9203(90)90303-V 
106. Franzen L, Wahlin B, Wahlgren M, Aslund L, Perlmann P, Wigzell H, et al. Enhancement or inhibition of Plasmodium falciparum erythrocyte reinvasion in vitro by antibodies to an asparagine rich protein. Mol Biochem Parasitol (1989) 32:201-11. doi:10.1016/0166-6851(89)90071-6

107. Biryukov S, Angov E, Landmesser ME, Spring MD, Ockenhouse CF, Stoute JA. Complement and antibody-mediated enhancement of red blood cell invasion and growth of malaria parasites. EBioMedicine (2016) 9:207-16. doi:10.1016/j.ebiom.2016.05.015

108. Jerusalem CR, Weiss ML, Poels LG. Immunologic enhancement in malaria infection (Plasmodium berghei). J Immunol (1971) 107:260-8.

109. Mendis KN, Peiris JSM, Premawansa S, Udagama PV, Munesinghe YD, Ranawaka $\mathrm{MB}$, et al. Immune modulation of parasite transmission in Plasmodium vivax malaria. Anti-gamete antibodies can both block and enhance transmission. In: Agabian N, Goodman H, Nogueira N, editors. Molecular Strategies of Parasite invasion.UCLA symposium on Molecular and Cellular Biology. New York: Alan R. Liss, Inc. (1987) 42:417-26.

110. Mattei DM, Sherf A, Bensaude O, Pereira da Silva LH. A heat shocklike protein from the human malaria parasite Plasmodium falciparum induces autoantibodies. Eur J Immunol (1989) 19:1823-8. doi:10.1002/eji. 1830191010

111. Do Rosario VE, Appiah A, Vaughan JA, Hollingdale MR. Plasmodium falciparum: administration of anti-sporozoite antibodies during sporogony results in production of sporozoites which are not neutralized by human anti-circumsporozoite protein sera. Trans R Soc Trop Med Hyg (1989) 83:305-7. doi:10.1016/0035-9203(89)90481-1

112. Motard A, Marussig M, Renia L, Baccam D, Landau I, Mattei DM, et al. Immunization with the malaria heat shock like protein hsp70-1 enhances transmission to the mosquito. Int Immunol (1995) 7:147-50. doi:10.1093/ intimm/7.1.147

113. Bopp SE, Manary MJ, Bright AT, Johnston GL, Dharia NV, Luna FL, et al. Mitotic evolution of Plasmodium falciparum shows a stable core genome but recombination in antigen families. PLoS Genet (2013) 9:e1003293. doi:10.1371/journal.pgen.1003293

114. Anders RF, Smythe JA. Polymorphic antigens in Plasmodium falciparum. Blood (1989) 74:1865-75.

115. Anders RF, Brown GV, Coppel RL, Kemp DJ. Repeat structures in malaria antigens. PNG Med J (1986) 29:87-93.

116. Thera MA, Doumbo OK, Coulibaly D, Laurens MB, Ouattara A, Kone AK, et al. A field trial to assess a blood-stage malaria vaccine. N Engl J Med (2011) 365:1004-13. doi:10.1056/NEJMoa1008115

117. Takala SL, Coulibaly D, Thera MA, Batchelor AH, Cummings MP, Escalante AA, et al. Extreme polymorphism in a vaccine antigen and risk of clinical malaria: implications for vaccine development. Sci Transl Med (2009) 1:2ra5. doi:10.1126/scitranslmed.3000257

118. Drew DR, Wilson DW, Elliott SR, Cross N, Terheggen U, Hodder AN, et al. A novel approach to identifying patterns of human invasioninhibitory antibodies guides the design of malaria vaccines incorporating polymorphic antigens. BMC Med (2016) 14:144. doi:10.1186/s12916-0160691-6

119. Neafsey DE, Juraska M, Bedford T, Benkeser D, Valim C, Griggs A, et al. Genetic diversity and protective efficacy of the RTS,S/AS01 malaria vaccine. N Engl J Med (2015) 373:2025-37. doi:10.1056/NEJMoa1505819

120. Yaneva R, Schneeweiss C, Zacharias M, Springer S. Peptide binding to MHC class I and II proteins: new avenues from new methods. Mol Immunol (2010) 47:649-57. doi:10.1016/j.molimm.2009.10.008

121. Blum JS, Wearsch PA, Cresswell P. Pathways of antigen processing. Annu Rev Immunol (2013) 31:443-73. doi:10.1016/j.vaccine.2009.06.069

122. Hennecke J, Wiley DC. T cell receptor-MHC interactions up close. Cell (2001) 104:1-4. doi:10.1016/S0092-8674(01)00185-4

123. De la Cruz VF, Maloy WL, Miller LH, Lal AA, Good MF, McCutchan TF. Lack of cross-reactivity between variant $\mathrm{T}$ cell determinants from malaria circumsporozoite protein. J Immunol (1988) 141:2456-60.

124. Zevering Y, Khamboonruang C, Good MF. Natural amino acid polymorphisms of the circumsprozoite protein of Plasmodium falciparum abrogate specific human CD4+ T cell responsiveness. Eur J Immunol (1994) 24:1418-25. doi:10.1002/eji.1830240627

125. Plebanski M, Lee EA, Hill AVS. Immune evasion in malaria: altered peptide ligands of the circumsporozoite protein. Parasitology (1997) 115:S55-66. doi:10.1017/S0031182097002035
126. Gilbert SC, Plebanski M, Gupta S, Morris J, Cox M, Aidoo MA, et al. Association of malaria parasite population structure, HLA, and immunological antagonism. Science (1998) 279:1173-7. doi:10.1126/science.279. 5354.1173

127. Plebanski M, Flanagan KL, Lee EA, Reece WH, Hart K, Gelder C, et al. Interleukin 10-mediated immunosuppression by a variant CD4 T cell epitope of Plasmodium falciparum. Immunity (1999) 10:651-60. doi:10.1016/ S1074-7613(00)80064-3

128. Plebanski M, Lee AM, Hanan CM, Flanagan KL, Gilbert SC, Gravenor $\mathrm{MB}$, et al. Altered peptide ligands narrow the repertoire of cellular immune responses by interfering with T-cell priming. Nat Med (1999) 5:565-71. doi:10.1038/8444

129. Brown $\mathrm{KN}$, Brown IN. Immunity to malaria: antigenic variation in chronic infections of Plasmodium knowlesi. Nature (1965) 208:1286-8. doi:10.1038/2081286a0

130. Brown KN. Antibody induced variation in malaria parasites. Nature (1973) 242:49-50. doi:10.1038/242049a0

131. Hommel M, David PH, Oligino LD. Surface alterations of erythrocytes in Plasmodium falciparum malaria antigenic variation, antigenic diversity, and the role of the spleen. JExp Med (1983) 157:1137-48. doi:10.1084/ jem.157.4.1137

132. Winter G, Kawai S, Haeggstrom M, Kaneko O, von Eule A, Kawazu S, et al. SURFIN is a polymorphic antigen expressed on Plasmodium falciparum merozoites and infected erythrocytes. JExp Med (2005) 201:1853-63. doi:10.1084/jem.20041392

133. al-Khedery B, Barnwell JW, Galinski MR. Antigenic variation in malaria: a 3' genomic alteration associated with the expression of a Plasmodium knowlesi variant antigen. Mol Cell (1999) 3:131-41. doi:10.1016/ S1097-2765(00)80304-4

134. Chan JA, Howell KB, Reiling L, Ataide R, Mackintosh CL, Fowkes FJ, et al. Targets of antibodies against Plasmodium falciparum-infected erythrocytes in malaria immunity. J Clin Invest (2012) 122:3227-38. doi:10.1172/JCI62182

135. Beeson JG, Chan JA, Fowkes FJ. PfEMP1 as a target of human immunity and a vaccine candidate against malaria. Expert Rev Vaccines (2013) 12:105-8. doi: $10.1038 / 71582$

136. Smith JD, Chitnis CE, Craig AG, Roberts DJ, Hudson-Taylor DE, Peterson DS, et al. Switches in expression of Plasmodium falciparum var genes correlate with changes in antigenic and cytoadherent phenotypes of infected erythrocytes. Cell (1995) 82:101-10. doi:10.1016/0092-8674(95)90056-X

137. Roberts DD, Sherwood JA, Spitalnik SL, Panton LJ, Howard RJ, Dixit VM, et al. Thrombospondin binds falciparum malaria parasitized erythrocytes and may mediate cytoadherence. Nature (1985) 318:64-6. doi:10.1038/ $318064 \mathrm{a} 0$

138. Oquendo P, Hundt E, Lawler JW, Seed B. CD36 directly mediates cytoadherence of Plasmodium falciparum parasitized erythrocytes. Cell (1989) 58:95-101. doi:10.1016/0092-8674(89)90406-6

139. Berendt AR, Simmons DL, Tansey J, Newbold C, Marsh K. Intercellular adhesion molecule- 1 is an endothelial cell adhesion receptor for Plasmodium falciparum. Nature (1989) 341:57-9. doi:10.1038/341057a0

140. Fried M, Duffy PE. Adherence of Plasmodium falciparum to chondroitin sulfate A in the human placenta. Science (1996) 272:1502-4. doi:10.1126/ science. 272.5267 .1502

141. Reeder JC, Cowman AF, Davern KM, Beeson JG, Thompson JK, Rogerson SJ, et al. The adhesion of Plasmodium falciparum-infected erythrocytes to chondroitin sulfate A is mediated by $P$. falciparum erythrocyte membrane protein 1. Proc Natl Acad Sci U S A (1999) 96:5198-202. doi:10.1073/pnas. 96.9.5198

142. Buffet PA, Gamain B, Scheidig C, Baruch DI, Smith JD, Hernandez-Rivas $\mathrm{R}$, et al. Plasmodium falciparum domain mediating adhesion to chondroitin sulfate A: a receptor for human placental infection. Proc Natl Acad Sci U S A (1999) 96:12743-8. doi:10.1073/pnas.96.22.12743

143. Ockenhouse CF, Tegoshi T, Maeno Y, Benjamin C, Ho M, Kan KE, et al. Human vascular endothelial cell adhesion receptors for Plasmodium falciparum-infected erythrocytes: roles for endothelial leukocyte adhesion molecule 1 and vascular cell adhesion molecule 1. J Exp Med (1992) 176:1183-9. doi:10.1084/jem.176.4.118

144. Siano JP, Grady KK, Millet P, Wick TM. Plasmodium falciparum: cytoadherence to alpha v beta3 on human microvascular endothelial cells. Am J Trop Med Hyg (1998) 59:77-9. 
145. Beeson JG, Rogerson SJ, Cooke BM, Reeder JC, Chai W, Lawson AM, et al. Adhesion of Plasmodium falciparum-infected erythrocytes to hyaluronic acid in placental malaria. Nat Med (2000) 6:86-90. doi:10.1038/71582

146. Treutiger CJ, Heddini A, Fernandez V, Muller WA, Wahlgren M. PECAM-1/ CD31, an endothelial receptor for binding Plasmodium falciparum-infected erythrocytes. Nat Med (1997) 3:1405-8. doi:10.1038/nm1297-1405

147. Biswas AK, Hafiz A, Banerjee B, Kim KS, Datta K, Chitnis CE. Plasmodium falciparum uses $\mathrm{gC} 1 \mathrm{qR} / \mathrm{HABP} 1 / \mathrm{p} 32$ as a receptor to bind to vascular endothelium and for platelet-mediated clumping. PLoS Pathog (2007) 3:1271-80. doi:10.1371/journal.ppat.0030130

148. Turner L, Lavstsen T, Berger SS, Wang CW, Petersen JE, Avril M, et al. Severe malaria is associated with parasite binding to endothelial protein $\mathrm{C}$ receptor. Nature (2013) 499:223-7. doi:10.1038/nature12361

149. Rowe JA, Moulds JM, Newbold CI, Miller LH. Plasmodium falciparum rosetting mediated by a parasite-variant erythrocyte membrane protein and complement-receptor 1. Nature (1997) 388:292-5. doi:10.1038/40888

150. Chen Q, Fernandez V, Sundstrom A, Schlichtherle M, Datta S, Hagblom P, et al. Developmental selection of var gene expression in Plasmodium falciparum. Nature (1998) 394:392-5. doi:10.1038/28660

151. Roberts DJ, Craig AG, Berendt AR, Pinches RA, Nash GB, Marsh K, et al. Rapid switching to multiple antigenic and adhesive phenotypes in malaria. Nature (1992) 357:689-92. doi:10.1038/357689a0

152. Blackman MJ, Scott-Finnigan TJ, Shai S, Holder AA. Antibodies inhibit the protease-mediated processing of a malaria merozoite surface protein. J Exp Med (1994) 180:389-93. doi:10.1084/jem.180.1.389

153. Carvalho BO, Lopes SC, Nogueira PA, Orlandi PP, Bargieri DY, Blanco YC, et al. On the cytoadhesion of Plasmodium vivax-infected erythrocytes. J Infect Dis (2010) 202:638-47. doi:10.1086/654815

154. Lopes SC, Albrecht L, Carvalho BO, Siqueira AM, Thomson-Luque R, Nogueira PA, et al. Paucity of Plasmodium vivax mature schizonts in peripheral blood is associated with their increased cytoadhesive potential. J Infect Dis (2014) 209:1403-7. doi:10.1093/infdis/jiu018

155. Carlton JMR, Adams JH, Silva JC, Bidwell SL, Lorenzi H, Caler E, et al. Comparative genomics of the neglected human malaria parasite Plasmodium vivax. Nature (2008) 455:757-63. doi:10.1038/nature07327

156. Neafsey DE, Galinsky K, Jiang RH, Young L, Sykes SM, Saif S, et al. The malaria parasite Plasmodium vivax exhibits greater genetic diversity than Plasmodium falciparum. Nat Genet (2012) 44:1046-50. doi:10.1038/ng.2373

157. Srivastava A, Gangnard S, Round A, Dechavanne S, Juillerat A, Raynal B, et al. Full-length extracellular region of the var2CSA variant of PfEMP1 is required for specific, high-affinity binding to CSA. Proc Natl Acad Sci U S A (2010) 107:4884-9. doi:10.1073/pnas.1000951107

158. Gangnard S, Lewit-Bentley A, Dechavanne S, Srivastava A, Amirat F, Bentley GA, et al. Structure of the DBL3X-DBL4epsilon region of the VAR2CSA placental malaria vaccine candidate: insight into DBL domain interactions. Sci Rep (2015) 5:14868. doi:10.1038/srep14868

159. Holder AA. The carboxy-terminus of merozoite surface protein 1: structure, specific antibodies and immunity to malaria. Parasitology (2009) 136: 1445-56. doi:10.1017/S0031182009990515

160. Ayi K, Turrini F, Piga A, Arese P. Enhanced phagocytosis of ring-parasitized mutant erythrocytes: a common mechanism that may explain protection against falciparum malaria in sickle trait and beta-thalassemia trait. Blood (2004) 104:3364-71. doi:10.1182/blood-2003-11-3820

161. Blackman MJ, Heidrich HG, Donachie S, McBride JS, Holder AA. A single fragment of a malaria merozoite surface protein remains on the parasite during red cell invasion and is the target of invasion-inhibiting antibodies. J Exp Med (1990) 172:379-82. doi:10.1084/jem.172.1.379

162. Guevara-Patino JA, Holder AA, McBride JS, Blackman MJ. Antibodies that inhibit malaria merozoite surface protein-1 processing and erythrocyte invasion are blocked by naturally acquired human antibodies. J Exp Med (1997) 186:1689-99. doi:10.1084/jem.186.10.1689

163. Okafor CM, Anumudu CI, Omosun YO, Uthaipibull C, Ayede I, Awobode HO, et al. Cellular response to modified Plasmodium falciparum MSP119 antigens in individuals previously exposed to natural malaria infection. Malar J (2009) 8:263. doi:10.1186/1475-2875-8-263

164. Ehrenstein MR, Notley CA. The importance of natural IgM: scavenger, protector and regulator. Nat Rev Immunol (2010) 10:778-86. doi:10.1038/ nri2849
165. Pleass RJ, Moore SC, Stevenson L, Hviid L. Immunoglobulin M: restrainer of inflammation and mediator of immune evasion by Plasmodium falciparum malaria. Trends Parasitol (2016) 32:108-19. doi:10.1016/j.pt.2015. 09.007

166. Ghumra A, Semblat JP, McIntosh RS, Raza A, Rasmussen IB, Braathen $\mathrm{R}$, et al. Identification of residues in the Cmu4 domain of polymeric IgM essential for interaction with Plasmodium falciparum erythrocyte membrane protein 1 (PfEMP1). J Immunol (2008) 181:1988-2000. doi:10.4049/ jimmunol.181.3.1988

167. Barfod LK, Dalgaard MB, Pleman ST, Ofori MF, Pleass RJ, Hviid L. Evasion of immunity to Plasmodium falciparum malaria by IgM masking of protective IgG epitopes in infected erythrocyte surface-exposed PfEMP1. Proc Natl Acad Sci U S A (2011) 108:12485-90. doi:10.1073/pnas.1103708108

168. Crosnier C, Iqbal Z, Knuepfer E, Maciuca S, Perrin AJ, Kamuyu G, et al. Binding of Plasmodium falciparum merozoite surface proteins DBLMSP and DBLMSP2 to human immunoglobulin $\mathrm{M}$ is conserved amongst broadly diverged sequence variants. J Biol Chem (2016) 291:14285-99. doi:10.1074/ jbc.M116.722074

169. Anders RF. Multiple cross-reactivities amongst antigens of Plasmodium falciparum impair the development of protective immunity against malaria. Parasite Immunol (1986) 8:529-35. doi:10.1111/j.1365-3024.1986. tb00867.x

170. Moir S, Ho J, Malaspina A, Wang W, DiPoto AC, O’Shea MA, et al. Evidence for HIV-associated B cell exhaustion in a dysfunctional memory B cell compartment in HIV-infected viremic individuals. J Exp Med (2008) 205:1797-805. doi:10.1084/jem.20072683

171. Portugal S, Tipton CM, Sohn H, Kone Y, Wang J, Li S, et al. Malaria-associated atypical memory B cells exhibit markedly reduced B cell receptor signaling and effector function. Elife (2015) 4:e07218. doi:10.7554/eLife.07218

172. Muellenbeck MF, Ueberheide B, Amulic B, Epp A, Fenyo D, Busse CE, et al. Atypical and classical memory B cells produce Plasmodium falciparum neutralizing antibodies. J Exp Med (2013) 210:389-99. doi:10.1084/ jem. 20121970

173. Fehr T, Bachmann MF, Bucher E, Kalinke U, Padova FED, Lang AB, et al. Role of repetitive antigen patterns for induction of antibodies against antibodies. J Exp Med (1997) 185:1785-92. doi:10.1084/jem.185.10.1785

174. Dintzis RZ, Okajima M, Middleton MH, Greene G, Dintzis HM. The immunogenicity of soluble haptenated polymers is determined by molecular mass and hapten valence. J Immunol (1989) 143:1239-44.

175. Zubler RH. Naive and memory B cells in T-cell-dependent and T-independent responses. Springer Semin Immunopathol (2001) 23:405-19. doi:10.1007/ s281-001-8167-7

176. Symer DE, Reim J, Dintzis RZ, Voss EW Jr, Dintzis HM. Durable elimination of high affinity, T cell-dependent antibodies by low molecular weight antigen arrays in vivo. J Immunol (1995) 155:5608-16.

177. Puentes F, Dickhaut K, Hofstatter M, Pfeil J, Lauer U, Hamann A, et al. Immune modulation and prevention of autoimmune disease by repeated sequences from parasites linked to self antigens. J Neuroimmune Pharmacol (2016). doi:10.1007/s11481-016-9701-x

178. Robson KJH, Hall JR, Davies LC, Crisanti A, Hill AVS, Wellems TE. Polymorphism of the TRAP gene of Plasmodium falciparum. Proc Biol Sci (1990) 242:205-16. doi:10.1098/rspb.1990.0126

179. Muller HM, Scarselli E, Crisanti A. Thrombospondin related anonymous protein (TRAP) of Plasmodium falciparum in parasite-host cell interactions. Parassitologia (1993) 35:69-72.

180. Trottein F, Triglia T, Cowman AF. Molecular cloning of a gene from Plasmodium falciparum that codes for a protein sharing motifs found in adhesive molecules from mammals and plasmodia. Mol Biochem Parasitol (1995) 74:129-41. doi:10.1016/0166-6851(95)02489-1

181. Chattopadhyay R, Rathore D, Fujioka H, Kumar S, De la Vega P, Haynes D, et al. PfSPATR - a Plasmodium falciparum protein containing an altered thrombospondin type I repeat domain is expressed at several stages of the parasite life cycle and is the target of inhibitory antibodies. J Biol Chem (2003) 278:25977-81. doi:10.1074/jbc.M300865200

182. Siddiqui FA, Dhawan S, Singh S, Singh B, Gupta P, Pandey A, et al. A thrombospondin structural repeat containing rhoptry protein from Plasmodium falciparum mediates erythrocyte invasion. Cell Microbiol (2013) 15:1341-56. doi:10.1111/cmi.12118 
183. Cowman AF, Berry D, Baum J. The cell biology of disease: the cellular and molecular basis for malaria parasite invasion of the human red blood cell. J Cell Biol (2012) 198:961-71. doi:10.1083/jcb.201206112

184. Chen L, Lopaticki S, Riglar DT, Dekiwadia C, Uboldi AD, Tham WH, et al. An EGF-like protein forms a complex with PfRh5 and is required for invasion of human erythrocytes by Plasmodium falciparum. PLoS Pathog (2011) 7:e1002199. doi:10.1371/journal.ppat.1002199

185. Kaslow DC, Quakyi IA, Syin C, Raum MG, Keister DB, Coligan JE, et al. A vaccine candidate from the sexual stage of human malaria that contains EGF-like domains. Nature (1988) 333:74-6. doi:10.1038/333074a0

186. Duffy PE, Kaslow DC. A novel malaria protein, Pfs 28 , and Pfs 25 are genetically linked and synergistic as falciparum malaria transmission-blocking vaccines. Infect Immun (1997) 65:1109-13.

187. Urban BC, Roberts DJ. Malaria, monocytes, macrophages and myeloid dendritic cells: sticking of infected erythrocytes switches off host cells. Curr Opin Immunol (2002) 14:458-65. doi:10.1016/S0952-7915(02)00368-0

188. McGilvray ID, Serghides L, Kapus A, Rotstein OD, Kain KC. Nonopsonic monocyte/macrophage phagocytosis of Plasmodium falciparum-parasitized erythrocytes: a role for CD36 in malarial clearance. Blood (2000) 96:3231-40.

189. Schwarzer E, Turrini F, Ulliers D, Giribaldi G, Ginsburg HD, Arese P. Impairment of macrophage functions after ingestion of Plasmodium falciparum-infected erythrocytes or isolated malarial pigment. J Exp Med (1992) 176:1033-41. doi:10.1084/jem.176.4.1033

190. Cunnington AJ, Njie M, Correa S, Takem EN, Riley EM, Walther M. Prolonged neutrophil dysfunction after Plasmodium falciparum malaria is related to hemolysis and heme oxygenase-1 induction. J Immunol (2012) 189:5336-46. doi:10.4049/jimmunol.1201028

191. Schwarzer E, Arese P. Phagocytosis of malarial pigment hemozoin inhibits NADPH-oxidase activity in human monocyte-derived macrophages. Biochim Biophys Acta (1996) 1316:169-75. doi:10.1016/0925-4439(96) 00021-X

192. Steinman RM. Decisions about dendritic cells: past, present, and future. Annu Rev Immunol (2012) 30:1-22. doi:10.1146/annurev-immunol-100311102839

193. Urban BC, Ferguson DJP, Pain A, Willcox N, Plebanski M, Austyn JM, et al. Plasmodium falciparum-infected erythrocytes modulate the maturation of dendritic cells. Nature (1999) 400:73-7. doi:10.1038/21900

194. Toure Balde A, Sarthou JL, Aribot G, Michel P, Trape JF, Rogier C, et al. Plasmodium falciparum induces apoptosis in human mononuclear cells. Infect Immun (1996) 64:744-50.

195. Helmby H, Jonsson G, Troye-Blomberg M. Cellular changes and apoptosis in the spleens and peripheral blood of mice infected with blood-stage Plasmodium chabaudi chabaudi AS. Infect Immun (2000) 68:1485-90. doi:10.1128/IAI.68.3.1485-1490.2000

196. Wykes MN, Zhou YH, Liu XQ, Good MF. Plasmodium yoelii can ablate vaccine-induced long-term protection in mice. JImmunol (2005) 175: 2510-6. doi:10.4049/jimmunol.175.4.2510

197. Woodberry T, Minigo G, Piera KA, Amante FH, Pinzon-Charry A, Good MF, et al. Low-level Plasmodium falciparum blood-stage infection causes dendritic cell apoptosis and dysfunction in healthy volunteers. J Infect Dis (2012) 206:333-40. doi:10.1093/infdis/jis366

198. Matsumoto J, Kawai S, Terao K, Kirinoki M, Yasutomi Y, Aikawa M, et al. Malaria infection induces rapid elevation of the soluble Fas ligand level in serum and subsequent $\mathrm{T}$ lymphocytopenia: possible factors responsible for the differences in susceptibility of two species of Macaca monkeys to Plasmodium coatneyi infection. Infect Immun (2000) 68:1183-8. doi:10.1128/ IAI.68.3.1183-1188.2000

199. Pinzon-Charry A, Woodberry T, Kienzle V, McPhun V, Minigo G, Lampah DA, et al. Apoptosis and dysfunction of blood dendritic cells in patients with falciparum and vivax malaria. JExp Med (2013) 210:1635-46. doi:10.1084/jem.20121972

200. Carvalho LJ, Ferreira-da-Cruz MF, Daniel-Ribeiro CT, Pelajo-Machado M, Lenzi HL. Plasmodium berghei ANKA infection induces thymocyte apoptosis and thymocyte depletion in CBA mice. Mem Inst Oswaldo Cruz (2006) 101:523-8. doi:10.1590/S0074-02762006000500007

201. Theander TG, Bygbjerg IC, Jacobsen L, Jepsen S, Larsen PB, Kharazmi A. Low parasite specific $\mathrm{T}$ cell response in clinically immune individuals with low grade Plasmodium falciparum parasitaemia. Trans R Soc Trop Med Hyg (1986) 80:1000-1. doi:10.1016/0035-9203(86)90295-6
202. Martini F, Paglia MG, Montesano C, Enders PJ, Gentile M, Pauza CD, et al. Vgamma9Vdelta2 T-cell anergy and complementarity-determining region 3 -specific depletion during paroxysm of nonendemic malaria infection. Infect Immun (2003) 71:2945-9. doi:10.1128/IAI.71.5.2945-2949.2003

203. Alves FA, Pelajo-Machado M, Totino PR, Souza MT, Goncalves EC, Schneider MP, et al. Splenic architecture disruption and parasite-induced splenocyte activation and anergy in Plasmodium falciparum-infected Saimiri sciureus monkeys. Malar J (2015) 14:128. doi:10.1186/s12936-0150641-3

204. Illingworth J, Butler NS, Roetynck S, Mwacharo J, Pierce SK, Bejon P, et al. Chronic exposure to Plasmodium falciparum is associated with phenotypic evidence of B and T cell exhaustion. J Immunol (2012) 190:1038-47. doi:10.4049/jimmunol.1202438

205. Butler NS, Moebius J, Pewe LL, Traore B, Doumbo OK, Tygrett LT, et al. Therapeutic blockade of PD-L1 and LAG-3 rapidly clears established bloodstage Plasmodium infection. Nat Immunol (2012) 13:188-95. doi:10.1038/ ni. 2180

206. Karunarathne DS, Horne-Debets JM, Huang JX, Faleiro R, Leow CY, Amante $\mathrm{FH}$, et al. Programmed death-1 ligand 2-mediated regulation of the PD-L1 to PD-1 axis is essential for establishing CD4+ T cell immunity. Immunity (2016) 45:333-45. doi:10.1016/j.immuni.2016.07.017

207. Horne-Debets JM, Karunarathne DS, Faleiro RJ, Poh CM, Renia L, Wykes MN. Mice lacking programmed cell death-1 show a role for CD8+ T cells in long-term immunity against blood-stage malaria. Sci Rep (2016) 6:26210. doi:10.1038/srep26210

208. Kho S, Marfurt J, Handayuni I, Pava Z, Noviyanti R, Kusuma A, et al. Characterization of blood dendritic and regulatory $\mathrm{T}$ cells in asymptomatic adults with sub-microscopic Plasmodium falciparum or Plasmodium vivax infection. Malar J (2016) 15:328. doi:10.1186/s12936-016-1382-7

209. Cambos M, Belanger B, Jacques A, Roulet A, Scorza T. Natural regulatory $\mathrm{CD} 4+\mathrm{CD} 25+\mathrm{FOXP}+\mathrm{T}$ cells control the production of pro-inflammatory cytokines during Plasmodium chabaudi adami infection and do not contribute to immune evasion. Int J Parasitol (2008) 38:229-38. doi:10.1016/j. ijpara.2007.07.006

210. Hisaeda H, Tetsutani K, Imai T, Moriya C, Tu L, Hamano S, et al. Malaria parasites require TLR9 signaling for immune evasion by activating regulatory T cells. J Immunol (2008) 180:2496-503. doi:10.4049/jimmunol.180. 4.2496

211. Kho S, Marfurt J, Noviyanti R, Kusuma A, Piera KA, Burdam FH, et al. Preserved dendritic cell HLA-DR expression and reduced regulatory T cell activation in asymptomatic Plasmodium falciparum and P. vivax Infection. Infect Immun (2015) 83:3224-32. doi:10.1128/IAI.00226-15

212. Hafalla JCR, Claser C, Couper KN, Grau GE, Renia L, De Souza JB, et al. The CTLA-4 and PD-1/PD-L1 inhibitory pathways independently regulate host resistance to Plasmodium-induced acute immune pathology. PLoS Pathog (2012) 8:e1002504. doi:10.1371/journal.ppat.1002504

213. Iyer JK, Gruner AC, Renia L, Snounou G, Preiser PR. Invasion of host cells by malaria parasites: a tale of two protein families. Mol Microbiol (2007) 65:231-49. doi:10.1111/j.1365-2958.2007.05791.x

214. Mayer DCG, Mu JB, Feng X, Su XZ, Miller LH. Polymorphism in a Plasmodium falciparum erythrocyte-binding ligand changes its receptor specificity. J Exp Med (2002) 196:1523-8. doi:10.1084/jem.20020750

215. Stubbs J, Simpson KM, Triglia T, Plouffe D, Tonkin CJ, Duraisingh MT, et al. Molecular mechanism for switching of Plasmodium falciparum invasion pathways into human erythrocytes. Science (2005) 309:1384-7. doi:10.1126/ science. 1115257

216. Persson KE, McCallum FJ, Reiling L, Lister NA, Stubbs J, Cowman AF, et al. Variation in use of erythrocyte invasion pathways by Plasmodium falciparum mediates evasion of human inhibitory antibodies. JClin Invest (2008) 118:342-51. doi:10.1172/JCI32138

217. Crosnier C, Bustamante LY, Bartholdson SJ, Bei AK, Theron M, Uchikawa M, et al. Basigin is a receptor essential for erythrocyte invasion by Plasmodium falciparum. Nature (2011) 480:534-7. doi:10.1038/nature10606

218. Douglas AD, Baldeviano GC, Lucas CM, Lugo-Roman LA, Crosnier C, Bartholdson SJ, et al. A PfRH5-based vaccine is efficacious against heterologous strain blood-stage infection in Aotus monkeys. Cell Host Microbe (2015) 17:130-9. doi:10.1016/j.chom.2014.11.017

219. Douglas AD, Williams AR, Illingworth JJ, Kamuyu G, Biswas S, Goodman $\mathrm{AL}$, et al. The blood-stage malaria antigen PfRH5 is susceptible to vaccine- 
inducible cross-strain neutralizing antibody. Nat Commun (2011) 2:601. doi:10.1038/ncomms1615

220. Zimmerman PA, Ferreira MU, Howes RE, Mercereau-Puijalon O. Red blood cell polymorphism and susceptibility to Plasmodium vivax. Adv Parasitol (2013) 81:27-76. doi:10.1016/B978-0-12-407826-0.0000

221. Miller LH, Mason SJ, Clyde DF, McGinniss MH. The resistance factor to Plasmodium vivax in blacks. The Duffy-blood-group genotype, FyFy. N Engl J Med (1976) 295:302-4. doi:10.1056/NEJM197608052950602

222. Livingstone FB. The Duffy blood groups, vivax malaria, and malaria selection in human populations: a review. Hum Biol (1984) 56:413-25.

223. Menard D, Barnadas C, Bouchier C, Henry-Halldin CN, Gray LR, Ratsimbasoa A, et al. Plasmodium vivax clinical malaria is commonly observed in Duffy-negative Malagasy people. Proc Natl Acad Sci U S A (2010) 107:5967-71. doi:10.1073/pnas.0912496107

224. Mendes C, Dias F, Figueiredo J, Mora VG, Cano J, de Sousa B, et al. Duffy negative antigen is no longer a barrier to Plasmodium vivaxmolecular evidences from the African West Coast (Angola and Equatorial Guinea). PLoS Negl Trop Dis (2011) 5:e1192. doi:10.1371/journal.pntd. 0001192

225. Abdelraheem MH, Albsheer MM, Mohamed HS, Amin M, Abdel Hamid MM. Transmission of Plasmodium vivax in Duffy-negative individuals in central Sudan. Trans R Soc Trop Med Hyg (2016) 110:258-60. doi:10.1093/ trstmh/trw014

226. Lo E, Yewhalaw D, Zhong D, Zemene E, Degefa T, Tushune K, et al. Molecular epidemiology of Plasmodium vivax and Plasmodium falciparum malaria among Duffy-positive and Duffy-negative populations in Ethiopia. Malar J (2015) 14:84. doi:10.1186/s12936-015-0596-4

227. Ngassa Mbenda HG, Das A. Molecular evidence of Plasmodium vivax mono and mixed malaria parasite infections in Duffy-negative native Cameroonians. PLoS One (2014) 9:e103262. doi:10.1371/journal.pone.0103262

228. Rosenberg RL. Plasmodium vivax in Africa: hidden in plain sight? Trends Parasitol (2007) 23:193-6. doi:10.1016/j.pt.2007.02.009

229. Ntumngia FB, Thomson-Luque R, de Menezes Torres L, Gunalan K, Carvalho LH, Adams JH. A novel erythrocyte binding protein of Plasmodium vivax suggests an alternate invasion pathway into Duffy-Positive reticulocytes. MBio (2016) 7:e1261. doi:10.1128/mBio.01261-16

230. Fang XD, Kaslow DC, Adams JH, Miller LH. Cloning of the Plasmodium vivax Duffy receptor. Mol Biochem Parasitol (1991) 44:125-32. doi:10.1016/ 0166-6851(91)90228-X

231. Cogswell FB. The hypnozoite and relapse in primate malaria. Clin Microbiol $\operatorname{Rev}(1992)$ 5:26-35. doi:10.1128/CMR.5.1.26

232. Fairley NH. Chemotherapeutic suppression and prophylaxis in malaria. An experimental investigation undertaken by medical research teams in Australia. Trans R Soc Trop Med Hyg (1945) 38:311-65. doi:10.1016/ 0035-9203(45)90038-1

233. Krotoski WA, Garnham PCC, Bray RS, Krotoski DM, Killick-Kendrick R, Draper CC, et al. Observations on early and late post-sporozoite tissue stages in primate malaria. I. The discovery of a new latent form of Plasmodium cynomolgi (the hypnozoite), and failure to detect forms within the first 24 hours after infection. Am J Trop Med Hyg (1982) 31:24-35.

234. Mikolajczak SA, Vaughan AM, Kangwanrangsan N, Roobsoong W, Fishbaugher M, Yimamnuaychok N, et al. Plasmodium vivax liver stage development and hypnozoite persistence in human liver-chimeric mice. Cell Host Microbe (2015) 16:526-35. doi:10.1016/j.chom.2015.02.011

235. Krotoski WA, Bray RS, Garnham PCC, Gwadz RW, Killick-Kendrick R, Draper CC, et al. Observations on early and late post-sporozoite tissue stages in primate malaria. II. The hypnozoite of Plasmodium cynomolgi bastianellii from 3 to 105 days after infection, and detection of 36- to 40-hour pre-erythrocytic forms. Am J Trop Med Hyg (1982) 31:211-25.
236. Krotoski WA, Krotoski DM, Garnham PCC, Bray RS, Killick-Kendrick R, Draper CC, et al. Relapses in primate malaria: discovery of two populations of exoerythrocytic stages. Preliminary note. Br Med J (1980) 280:153-4. doi:10.1136/bmj.280.6208.153-a

237. Mazier D, Renia L, Snounou G. A pre-emptive strike against malaria’s stealthy hepatic forms. Nat Rev Drug Discov (2009) 8:854-64. doi:10.1038/ $\operatorname{nrd} 29$

238. Garnham PCC, Bray RS. The influence of immunity upon the stages (including late exo-erythrocytic schizonts) of mammalian malaria parasites. Rev Bras Malariol Doencas Trop (1956) 8:151-60.

239. Shortt HE, Garnham PCC. The pre-erythrocytic stage of human malaria, Plasmodium vivax. Br Med J (1948) 1:547. doi:10.1136/bmj.1.4550.547

240. Shortt HE, Fairley NH. The pre-erythrocytic stage of Plasmodium falciparum; a preliminary note. $\mathrm{Br}$ Med J (1949) 2:1006-8. doi:10.1136/bmj.2. 4635.1006

241. Coquelin F, Boulard Y, Mora-Silvera E, Richard F, Chabaud AG, Landau I. Final stage of maturation of the erythrocytic schizonts of rodent Plasmodium in the lungs. C R Acad Sci (1999) 322:55-62. doi:10.1016/S0764-4469 (99)80017-1

242. Baer K, Klotz C, Kappe SH, Schnieder T, Frevert U. Release of hepatic Plasmodium yoelii merozoites into the pulmonary microvasculature. PLoS Pathog (2007) 3:e171. doi:10.1371/journal.ppat.0030171

243. Fajardo LF. The role of platelets in infections. I. Observations in human and murine malaria. Arch Pathol Lab Med (1979) 103:131-4.

244. Mora-Silvera E, Coquelin F, Vuong P, Deharo E, Gautret P, Renia L, et al. Role of macrophages as possible transporters of Plasmodium yoelii nigeriensis merozoites through the lymphatic system. Preliminary note. Parasite (1997) 4:83-5. doi:10.1051/parasite/1997041083

245. Wykes MN, Kay JG, Manderson A, Liu XQ, Brown DL, Richard DJ, et al. Rodent blood-stage Plasmodium survive in dendritic cells that infect naive mice. Proc Natl Acad Sci U S A (2011) 108:11205-10. doi:10.1073/ pnas. 1108579108

246. Boulard Y, Coquelin F, Mora-Silvera E, Renia L, Gautret P, Deharo E, et al. Dendritic leucocytes as possible carriers of murine Plasmodium merozoites. Parasite (1996) 3:383-6. doi:10.1051/parasite/1996034383

247. Landau I, Chabaud AG, Vuong PN, Deharo E, Gautret P. Circulation in the lymphatic system and latency of Plasmodium merozoites. Preliminary note. Parasite (1995) 2:185-6. doi:10.1051/parasite/1995022185

248. Landau I, Chabaud AG, Mora-Silvera E, Coquelin F, Boulard Y, Renia L, et al. Survival of rodent malaria merozoites in the lymphatic network: potential role in chronicity of the infection. Parasite (1999) 6:311-22. doi:10.1051/ parasite/1999064311

249. Carter RL, Mendis KN. Evolutionary and historical aspects of the burden of malaria. Clin Microbiol Rev (2002) 15:564-94. doi:10.1128/ CMR.15.4.564-594.2002

250. Cox FEG. Malaria. Cloning genes for antigens of Plasmodium falciparum. Nature (1983) 304:13-4. doi:10.1038/304013a0

Conflict of Interest Statement: The authors declare that the research was conducted in the absence of any commercial or financial relationships that could be construed as a potential conflict of interest.

Copyright (ㄷ) 2016 Rénia and Goh. This is an open-access article distributed under the terms of the Creative Commons Attribution License (CC BY). The use, distribution or reproduction in other forums is permitted, provided the original author(s) or licensor are credited and that the original publication in this journal is cited, in accordance with accepted academic practice. No use, distribution or reproduction is permitted which does not comply with these terms. 